\title{
プルトニウムの安全性の基礎
}

\section{Scientific Bases for Radiological Safety of Plutonium}

\author{
（1994年 8 月 2 日 受 理）
}

Puに対する社会的関心が高い。たしかにPuの幾つかの同位体は核分裂性であり，また放射線 䓯性の高い物質の一つである。しかし，その実態に対する理解は必ずしす十分ではなく，そのこ とのゆえ，ときに一部から意図的に部分的誇張を含む説明がなされたりすることさえある。

本「特集」では，Puの安全性を考える基礎として，生体に対する影響を中心に，放射線毒性学の 観点加ら Puの実像を概観する。

（担当編集委員·稲葉次郎, 三村 均)

I、はじめに

II 、プルトニウム利用の現状と動向

III. 安全性に関保するプルトニウムの物理化学的性格

IV. ブルトニウムの生体内挙動と線量評価

V. プルトニウムの生物影響 (動物実験とそのリスク)
VI. 人体での䂓察

VI. プルトニウムの安全管理(作業環境の 放射線管理と個人モ二タリング)

VIII. 環境中のプルトニウム

IX。书わりに

\section{I.はじめに}

電力中央研究所 松 岡 理

原子力分野でのプルトニウム $(\mathrm{Pu})$ の利用は今 や新しい段陵に達して来ている。核然料サイクル の環がいろいろな形で完成され, 高速堌殖原型炉 「あんじゅ」の初臨界, 新型転換炉(ATR)でのPu 利用以外にあ軽水炉でのリサイクルも $\mathrm{Pu} \cdot \mathrm{U}$ 混合 酸化物 (MOX) 燃料の海外調達など具体的な計画 が進められている。また返還ガラス固化体の中間 眝蔵においてさえ $\mathrm{Pu}$ の存在が問題になり，核然 料サイクルのあらゆる場面で Puの安全性が問題 になるようになってきた。このことは今後，従来 よりも Puの安全性の問題がより広く, より樑く 議論される機会が増しているといえよう。そして 同時に, 本学会会員は好むと好まざるとにかかわ らず，一般の公衆とのPuの安全性の論議に参加 せざるをえない場合が増大するであろう。この時 にはご自分の専門分野以外に $\mathrm{Pu}$ そのあのについ ての広範囲の知識が必要になる。本「特集」はこの ような場合に少しであ役立っことを願って，安全 性に関連する各分野の専門家の手を煩わしてま之 められたものである。
まず，「プルトニウム利用の現状と動向」と題し て，動燃事業団を中心とする最近のPuに関する 動向を紹介し，我が国の置かれている状況を把握 することに役立っことを願っている。

第 2 に，「プルトニウムの物理化学的性格」と題 して，化学的性格を中心とする安全性に関連する $\mathrm{Pu}$ の諸特性を紹介することにより，Puそのあの に対する理解を梁めるとともに，人体への移行の 問題を考える基礎として役立たせることを願って いる。

第 3 K，「プルトニゥムの生体内举動と線量評 価」と題して, 体内での挙動とそれとの関連での 線量評価を論ずることにより，Puによる内部被 曝の特徽を被曝線量の観点から理解することに役 立てることを願っている。

第 4 に，「プルトニゥムの生物影害」と題して, 一般的な放射線影響とは異なる $\alpha$ 放射体としての $\mathrm{Pu}$ の生物影響の特徴を理解するのに役立てよう とするすのである。

第 5 に，「人体での観察」と題するものは，人体 死亡例のない人体での過剩被曝の集団の具体例を 紹介することにより，Puの人体影響の本質，そ して実態を明らかにしょうとするものである。

第 6 K，「プルトニウムの安全管理と個人モニ 
タリング」では, Puの可能性のある被曝の第一は やはり職業被曝であるから，作業環境での安全管 理が最も重要であり，その証拠としての個人モ二 タリングがいかに行われているか，問題を理解す る上で重要である。

第 7 に，「環境中のプルトニウム」については， いろいろな原因で環境に拡散したPuについての 知識を得ることは，核然料サイクルの拡大に伴う 将来の $\mathrm{Pu}$ の環境への拡散を占う点で意義がある と考えられる。これらの文章の内容を我が身のあ のとして一般人に話しかけて貪いたいと念ずるす のである。

現在Puの安全が公衆の間に問題とされるのは, 我が国の原子力政策に対する社会的な批判ととも に, Puの安全性についてのかなり誇張された情 報が公䍃の素朴な共感を得ている点ああるのであ る。少なくとも不当な誤解に基づく $\mathrm{Pu}$ に対する
誤った認識だけは正しておくことが, 原子力問題 に対する社会の認識を高める上で肝要である。し たがって，対策の第一は，Puの安全に関連する 正確な情報の公衆への伝達の努力である。このた めには原子力分野で働く者すべてが, 自分の専門 分野を超えて安全に関する情報の伝達に努めるこ とが必要である。日常の会話で何気なく一般の人 に話しかけられたときの学会員の反応は非常に大 きな影響を与えるすのである。原子力の専門家で さえ答えられなかったとか, 原子力の専門家でさ えこんな重要なことを知らなかったなどと一般の 人は受け止めるのである。

原子力は今や厳しい社会環境の中にある, 本学 会会員たるもの己のよってたつ基盤をより強固な あのにするために各自の分野で努力するととも に, 広く公衆の理解を高めるための努力を払いた いものである。

\section{II. プルトニゥム利用の現状と動向}

動力炉·核燃料開発事業団 安 藤 久隆

\section{1.はじめに}

本年(1994年) 4 月， Pu 利用技術開発の大きな節 目ともいうべき高速増殖原型炬「あんじゅ」が初臨 界を達成した。このタイミングに「本特集」を組ま れたことは, 大変意義深いことといえる。本章で は, $\mathrm{Pu}$ 利用の歴史を顧みるとともに, 動燃事業 団におけるPuの利用情況を紹介し，Puを巡る最 近の動向に触れることとしたい。

\section{Pu利用と钶燃事業団}

\section{（1）動燃事業団の設立}

我が国は，1955年(昭30)に原子力基本法を制定 し, 将来の重要なエネルギー源の一つとして原子 力の開発に着手した。その後策定された原子力長 期計画により, 使用斉の核燃料は再処理し, 将来 的にはウラン資源を最も有効に利用できる高速增 殖炉で利用するという，いわゆる $\mathrm{Pu}$ 利用再処理 路線が示された。この施策を受けて1967年, 我が 国の核㜣料サイクル技術を開発することを目的
に, 当時, 原子燃料の開発を進めていた原子燃料 公社を発展的に改組して動力炬・核燃料開発事業 団(動燃)を発足させた。

\section{(2) $\mathrm{Pu}$ 利用の経緯}

$\mathrm{Pu}$ を燃料として使用する技術開発は1966年, 原子燃料公社が茨城県東海村に建設したプルトニ ウム燃料第一開発室に約 $200 \mathrm{~g}$ の $\mathrm{Pu}$ を荷したこ とに始まるといえる。ここでの燃料製造に係る基 礎的な研究成果を基に1972年, 高速堌殖実験炉 「常陽」および新型転換炬原型炬「ふげん」の $\mathrm{Pu} ・ \mathrm{U}$ 混合酸化物然料(MOX 燃料)を開発·製造するため, プルトニゥム燃料第二開発室が完成した。

当時は，Puを国内では調達できないため，米 国や欧州からPuを睡入したり，海外委託再処理 で回収されたPuを輸送して使用してきた。1978 年には, 日·米再処理協議が行われ, 東海再処理工 場から回収されるPuをマイクロ波加熱直接脱硝 法による Pu・U混合転換により行うことで決着を みて, 東海再処理工場が運転を開始した。しかし, 当時の転換のための設備は, プルトニウム燃料第 二開発室内に設置された小規模のものであった。

この試験設備による実績を基に1983年, プルト ニウム転換技術開発室を完成させた。この施設の 
運転開始で，我が国の核燃料サイクル施設が一通 り整ったことになる。さらに，1985年には，高速 増殖原型炬「むんじゅ」执よび「常陽」の燃料製造を 目的に，自動・遠隔化技術を取り入れたプルトニ ウム燃料第三開発施設が操業を開始した。

\section{(3) Pu利用の現状}

1992年12月末までの Pu 利用状況は, 東海再処 理工場から回収された原料 $\mathrm{Pu}$ と海外加ら輸入さ れた原料 $\mathrm{Pu}$ を併せた供給量が約 $4.2 \mathrm{t}$ (核分裂性 $\mathrm{Pu}$ 量，以下同じ)であり，研究開発および「ふげん」, 「常陽」「むんじゅ」の MOX燃料製造に使用され

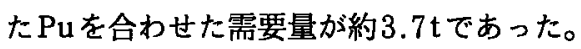

研究開発としては，Puの分析・測定試験, 二酸 化プルトニウム粉末の物性試験およびMOX然料 ペレットの物性試験等の基礎的な試験・研究, MOX燃料の照射試験用燃料の製造，ならびに各 種の臨界実験装置の燃料製造に使用された。

「ふげん」「常陽」の MOX 燃料製造としては, 同時期までに「ふげん」用 MOX 燃料が約 $91 \mathrm{t}$ MOX, 「常陽」用 MOX 燃料が約 5.3t MOX 製造さ れた。これらの製造経験を通してMOX燃料の基 本的な製造技術を確立した。一方，軽水炉燃料の 高燃焼度化に伴い，供給されるPuの同位体組成 の高次化が進み，燃料製造に係る放射線被曝対策 が大きな課題となり，装置の自動・遠隔化が必要 となった。

「むんじゅ」については，「ふげん」「常陽」の燃 料製造経験を踏まえ，自動・遠隔設備を備えた新 たな施設において，初装荷燃料を製造した。製造 経験を通して自動·遠隔化設備の保守, 自動化施設 におけるPuの工程内滞留等の課題に直面し，そ の課題を乗り越えるための努力を積み重ねてき た。

\section{（4）今後のPu利用計画}

動燃における今後のPu需給見通しは，供給量 として, 東海再処理工場から回収される Puが過 去の実績から年平均約 $0.4 \mathrm{t}$ 程度であり, 一方, 需要量として,「あんじゅ」,「常陽」,「ぶ゙ん」の MOX燃料製造用に年平均で約 $0.6 \mathrm{t}$ 程度である。

需要量に対して供給量が不足しているため, 将 来, 海外からPuを輸送することが必要になると 考えている。また，Pu利用に対する国内外の関
心の高まりに対応し，利用状況の透明性を高めて いくことが重要になってくると考えている。

\section{3. 保障措置制度と核不拡散}

原子力開発において重要視されるのは，安全の 確保之核不拡散である。国際的には1954年，国連 総会における当時の米国大統領アイゼンハワーの “Atoms for Peace” 演説が原子力平和利用の時代 の幕を開け，これ之同時に原子力の国際管理が考 えられ，1957年には国際原子力機関(IAEA)が設 立されている。「保障措置とは, 原子力の平和利 用のための資材,設備および装置がいかなる軍事 目的を助長するためにあ使用されないことを確保 するための管理の制度をいう」と定義されている が, IAEA は保障措置の要といえる。そしてこの 保障措置が, 現在の世界の原子力平和利用を核不 拡散と両立しつつ進めるための重要な要件となっ てきたことはよく知られている。

$\mathrm{Pu}$ 利用については, 米国の新しい核不拡散政 策が, Puの平和利用之核拡散の問題を直接結び 付けていること等加ら，Pu利用は政治や国際情 況に大きく影響を受ける。

また，Puについては，極めて厳格な管理が要 求される。動燃のプルトニウム燃料第三開発室の 工程内帯留の問題は, Puの粉末が燃料製造工程 のグローブボックスの中に付着等により滞留して いた問題であるが，その管理は簃重に実施されて おり，国およびIAEA の確認を受けている。

なお，工程内滞留はあらゅる観点から少ない方 がよいので, 動燃は現在,この滞留量を減少させ るための努力を行なっているところである。

いずれにしてす，Puの平和利用については, 経済的理由等から世界的に開発のテンポが遅れて いるが，今後，Pu利用を進めるためには核不拡 散の問題に積極的に取り組むことが必要となる。

\section{4.おわりに}

我が国は，エネルギー問題の解決や資源の有効 利用の観点から，Pu利用のための技術開発を着 実に実施してきた。一方，世界の人々のPuに対 する関心は，核不拡散の観点から以前にす増して 高まっている。このような $\mathrm{Pu}$ 利用に対する国際 
情勢の変化の中で, 我が国はエネルギーの安定供 給に貢献する観点から，着実に技術開発を進める
必要があると考える。このためにも核不拡散問題 の解決に積極的な貢献が不可欠であると考える。

\section{III. 安全性に関係するプルトニウム の物理化学的性格}

動力炉·核燃料開発事業団 小沢 正 基

\section{1.はじめに}

金属元素による生体の機能障害は，体内吸収に 基づく生化学的反応系の変化に起因する ${ }^{(1)}$ 。金属 の環境加ら生体への移行, 体内での吸収, 沈着, 排泄等, 一連の化学挙動はその物理化学的形状や 環境の溶液化学に支配される。本章では，安全評 価上重要と考えられるPu の基本的な物理化学性 状と環境溶液中での特徵的性格をまとめる。また アクチニド核種の分離において，重要な共存物質 である新しい有機抽出剤の生物学的安全性につい てあ若千言及する。

\section{2. $\mathrm{Pu}$ の形態と溶液化学の特徵}

$\mathrm{Pu}$ の存在形態や溶解性，また共存物質はその 安全性に密接に関連する。核燃料サイクルで取り 扱う $\mathrm{Pu}$ は原子炉内の連鎖反応により生ずる。酸 化物としては $\mathrm{PuO}, \mathrm{Pu}_{2} \mathrm{O}_{3}, \mathrm{PuO}_{2}$ の形態をとるが, 最も代表的な形態は $\mathrm{PuO}_{2}$ である。 $\mathrm{PuO}_{2}$ および $\mathrm{UO}_{2}$ 仕同じ結晶構造をとるので, 混合酸化物然料 中では全組成域にわたって固溶体を形成する。ち なみに使用済燃料中の $(\mathrm{U}, \mathrm{Pu}) \mathrm{O}_{2}$ 固溶体は, $\mathrm{CaF}_{2}$ 型面心立方構造であることが分析で確認されてい $る^{(2)}$ 。また高レベル廃液のガラス固化体中の $\mathrm{Pu}$ 屯酸化物として存在するあのとるられる。酸化物 の溶解性は再処理プロセスでの高濃度硝酸条件 下で詳細に検討されている。通常，硝酸へのUO の溶解は容易である。しかしながら $\mathrm{PuO}_{2}$ 単体は 難溶性で，製造に当たっての焼結温度にも依存し て，特に高温 $\left(>350^{\circ} \mathrm{C}\right)$ の場合，極めてその溶解は 難しい。混合酸化物燃料では，溶解性は $\mathrm{PuO}_{2}$ の 富化度の増加に従い低下し，50\%以上の富化度で は完全な溶解は困難となる ${ }^{(3)}$ 。そこでフッ酸や銀 触媒 $\left(\mathrm{Ag}^{2+}\right)$ を用いる $\mathrm{PuO}_{2}$ の溶解促進法が検討さ
れている。

$\mathrm{Pu}$ イオンは水溶液中で $+3 \sim+7$ の原子価をと る。主なイオン形態としては $\mathrm{Pu}^{3+}, \mathrm{Pu}^{4+}, \mathrm{PuO}_{2}{ }^{+}$, $\mathrm{PuO}_{2}{ }^{2+}$ の 4 種である。鉱酸 $\left(\mathrm{HClO}_{4}, 1 \mathrm{M}\right)$ 中の各イ オンの酸化還元電位は下記の通りである(4)。

$$
\begin{array}{cc}
\mathrm{Pu}^{4+}+e^{-}=\mathrm{Pu}^{3+} & E^{0}: 0.982 \mathrm{~V} \\
\mathrm{PuO}_{2}{ }^{+}+4 \mathrm{H}^{+}+e^{-}=\mathrm{Pu}^{4+}+2 \mathrm{H}_{2} \mathrm{O} & E^{0}: 1.172 \mathrm{~V} \\
\mathrm{PuO}_{2}{ }^{2+}+4 \mathrm{H}^{+}+2 e^{-}=\mathrm{Pu}^{4+}+2 \mathrm{H}_{2} \mathrm{O} \\
E^{0}: 1.043 \mathrm{~V} \\
\mathrm{PuO}_{2}{ }^{2+}+e^{-}=\mathrm{PuO}_{2}{ }^{+} & E^{0}: 0.913 \mathrm{~V}
\end{array}
$$

個々の酸化状態は適当な酸化・還元剤および錯 化剤によって安定化される。例えば，再処理の PUREXプロセス溶液ではいくつかの酸化還元反 応が競合して平衡が形成されるため, 複数の酸化 状態のPuイオンが共存することとなる。鉱酸中 ではPu(IV)の不均化が進む。

$$
\begin{aligned}
& 2 \mathrm{Pu}^{4+}+2 \mathrm{H}_{2} \mathrm{O}=\mathrm{Pu}^{3+}+\mathrm{PuO}_{2}{ }^{+}+4 \mathrm{H}^{+} \\
& \mathrm{Pu}^{4+}+\mathrm{PuO}_{2}{ }^{+}=\mathrm{Pu}^{3+}+\mathrm{PuO}_{2}{ }^{2+}
\end{aligned}
$$

すなわち,

$$
3 \mathrm{Pu}^{4+}+2 \mathrm{H}_{2} \mathrm{O}=2 \mathrm{Pu}^{3+}+\mathrm{PuO}_{2}^{2+}+4 \mathrm{H}^{+}
$$

また，Puイオンはそれ自体が加水分解したり， 酸素原子を含むアニオン配位子やハロゲンと錯体 形成反応を生ずる。錯化反応の傾向は受容Pu 1 オンのイオンポテンシャルに比例して増大し,

$$
\mathrm{Pu}^{4+}>\mathrm{Pu}^{3+}>\mathrm{PuO}_{2}{ }^{2+}>\mathrm{PuO}_{2}{ }^{+(4)(5)}
$$

である。生理学的溶液は種々の配位子や錯化イオ ンを含むので, $\mathrm{Pu}(\mathrm{IV})$ が生体内における安定な イオン形態の主体であることを同わせる。生理学 的な観点からも重要な Puの化学特性は，中性あ るいは低酸濃度条件で加水分解し, 熱力学的に安 定で相対的に不溶性の重合体が生成することであ る。このような条件での Pu イォンの加水分解反 応の傾向は次の通りである。

$$
\mathrm{Pu}^{4+}>\mathrm{PuO}_{2}{ }^{2+}>\mathrm{Pu}^{3+}>\mathrm{PuO}_{2}{ }^{+(5)(7)}
$$

重合化の機構はまず水和カチオン, $\mathrm{M}^{\mathrm{n}+}$ が加水分 
解することで開始される(6)。

$$
\begin{aligned}
& {\left[\mathrm{M}\left(\mathrm{H}_{2} \mathrm{O}\right)_{\mathrm{m}}\right]^{\mathrm{n}+}} \\
& \longrightarrow\left[\mathrm{M}(\mathrm{OH})\left(\mathrm{H}_{2} \mathrm{O}\right)_{\mathrm{m}-1}\right]^{(\mathrm{n}-1)+}+\mathrm{H}^{+}
\end{aligned}
$$

ここで, 水和水は水酸基に変換している。重合化 の初期は二量体の形態をとり，この二量重合反応 が連鎖することにより，長鎖重合体が形成され る。

$$
\left[\left(\mathrm{H}_{2} \mathrm{O}\right)_{\mathrm{m}-2}{ }_{\mathrm{OH}}^{\mathrm{MH}} \mathrm{M}\left(\mathrm{H}_{2} \mathrm{O}\right)_{\mathrm{m}-2}\right]^{2(\mathrm{n}-1)+}
$$

一般的に重合体の構造は時間とともに変化し，初 期では“オール錯体”構造をとるが，熟成によって 脱水が進み“オクソ”錯体となる。

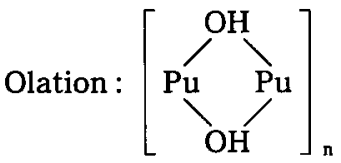

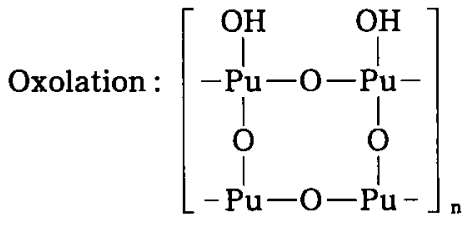

$\mathrm{Pu}$ (IV)重合体は加熱することによって, 熱力 学的にさらに安定な $\mathrm{PuO}_{2}$ に変化する。重合化は 低硝酸濃度 ( $\left.<1 \mathrm{M} \mathrm{HNO}_{3}\right)$, 高 $\mathrm{Pu}(\mathrm{IV})$ 濃度および高 温下で促進される傾向にある。重合反応は比較的 遅い非可逆プロセスであるが，熱濃硝酸条件や フッ素イオンの添加で解重合は進む。しかしなが らいったん熟成が進んだオクソ錯体の解重合は困 難である。

\section{3. 環境条件における Puの化学}

フォールアゥトに由来した Puの環境中での挙 動や廃棄物処分の安全性に検討を進める場合, 前 節で述べた溶液化学特性に自然水の種々の条件を 加味した評価が必要となる。環境条件下における アクチニド溶液化学の主な特徽は次のようにまと められる(7)(8)。

(1)自然水には種々の金属イオンや, $\mathrm{HCO}_{3}{ }^{-} / \mathrm{CO}_{3}{ }^{2-}, \mathrm{Cl}^{-}$等のアニオン, さらに腐 植酸, フルボ酸等の有機錯化剂が含まれる。
それらがアクチニドの化学種や錯体形成に 関与する。

（2）自然水の条件から, 環境中では加水分解 に上る水酸化物之炭酸塩錯体の形成が支配 的と考えられる。各錯体の生成定数, 固相 の解離定数等の熱力学的データから固相化 学種の溶解度が推定できる。

（3）環境溶液中の $\mathrm{Pu}$ 化学種は, $\mathrm{pH}$ 条件で異 なるが, III, IV, V 価が主要種である。還 元性条件下では, 炭酸塩の存在が Puの溶 解性を加速させる。海水中ではV 価が支配 的である(8)。

（4）中性に近い自然水条件 $(\mathrm{pH}=5 \sim 9)$ ではつ クチニドイオン, 特にIV価は加水分解反応 を受け易く重合性の水酸化コロイドとな る。また他のコロイドや微粒子と会合して 疑似コロイドを形成する。コロイド形態の 差異はアクチニドの移行プロセスに重要な 影響を及ぼす。

環境溶液中における $\mathrm{Pu}$ の化学種と溶解性につ いていくつかの実験例がある。第 III-1 図(7) $\mathrm{PuO}_{2}$ 単体および模擬ガラス固化体中の $\mathrm{Pu}$ の, 塩 化ナトリウム, 純水および地下水に対する溶解度 の例である。本図には此較のために $\mathrm{PuO}_{2}$ および $\mathrm{Pu}(\mathrm{OH})_{4}$ の, 炭酸および過塩素酸ナトリウム溶 液中での溶解度が曲線で示されている。これらの データから模擬環境溶液中で Puの溶解性は, 液 性および化学形態の如何を問わず著しく低いこと が読み取れる。例えば，海水条件 ( 8 前後の $\mathrm{pH}$ 值 を想定)では，溶解度は $10^{-10} \sim 10^{-6} \mathrm{~mol} / l$ の範囲 にあり，抒招む极熱力学デー夕に基づく計算值 ${ }^{(8)}$ に一致している。また $\mathrm{PuO}_{2}$ は $\mathrm{Pu}(\mathrm{OH})_{4}$ に比べて 溶解性が低いこと, 模擬ガラス固化体からのPu の溶出には，固化体成分との疑似コロイド形成の 可能性が高いことも示唆されている(7)。一方, $\mathrm{Pu}(\mathrm{IV})$ の重合体についても溶解度が調べられて おり ${ }^{(9)}$ ，その溶解性は,

$$
\begin{aligned}
& \mathrm{PuO}_{2}<\mathrm{Pu}(\mathrm{IV})<\mathrm{Pu}(\mathrm{OH})_{4} \\
& \text { (結晶)（重合体）（非晶質） }
\end{aligned}
$$

すなわち, 他化学種の中間程度であることが報告 されている。Pu(IV) 重合体は $\mathrm{pH}>5$ の条件にお いて不安定であるので, 地殼圈では重合体として 


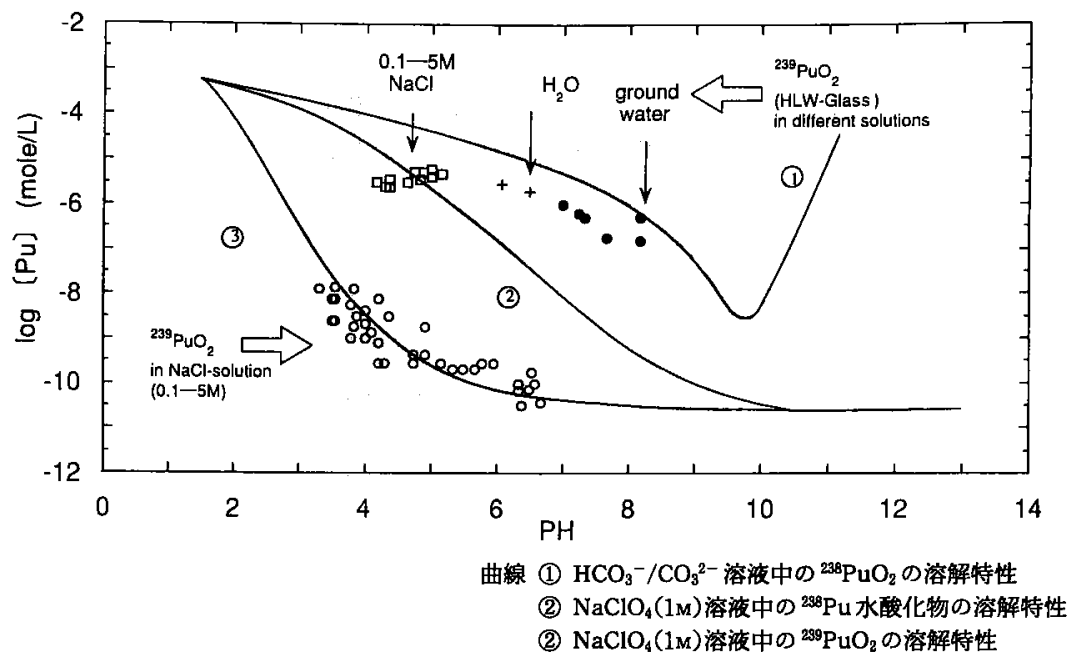

第 III-1 図 種々の溶液(塩化ナトリウム,純水,地下水)における ${ }^{239} \mathrm{PuO}_{2}$ (単体および模擬ガラス固化体中)の溶解度

移動しにくく，また長期間の熟成によって結晶性 が増し, $\mathrm{PuO}_{2}$ に变成する。したがって, 地款圈 での最終的な $\mathrm{Pu}$ の存在形態と溶解性は $\mathrm{PuO}_{2}$ (結 晶あるいは水和物)を主体に考えてよいであろう。 実際にハンフォードの污染土裹中のPuの化学形 態が調查されており ${ }^{(10)}, \mathrm{X}$ 線回折から結晶性 $\mathrm{PuO}_{2}$ の存在が確認されている。

ところで Patterson ら ${ }^{(11)}$ は， $\mathrm{PuO}_{2}$ ペレット中 のPuの各種溶液への溶解率を測定している。海 水へのPu溶解率の典型値として, 浸漬時間, 温度 等で異なるが, $20 n \mathrm{Ci} / \mathrm{m}^{2} \cdot \mathrm{s}$ (初期表面皘に対する秒 当たりの溶解率)を例示している。彼らはまた, 海 水への溶解率は純水に比へ明らかに遅いこと, 海 水中では昇温による溶解加速性は認められないこ とという，2つの特筆すべき傾向を挙げている。 地款圈での $\mathrm{Pu}$ を含むアクチニドの挙動は複雑で あるが，錯体の安定度定数, 固相の解離定数等の 熱力学データに基づく収着, 移送のモデル計算に 並行して, 有機錯体・コロイドの生成機構·安定性 および収着機構等の解明に主眼をおいた研究を進 めることで，より精繳な予測が可能となる。また 実際の化学形態や溶解性などのフィールドデータ の取得とそれによる検証も合わせて重要と考えら れる。なお主要アクチニド,核分裂生成物の地球 化学については，放射性廃棄物管理の安全性に関

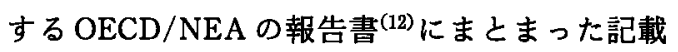
がある。

\section{4. 抽出剂の生物学的安全性}

$\mathrm{Pu}$ の安全性に関連して, アクチニド核種の分 離操作で用いる有機抽出剤の安全性を検討してい る。TBP (Tri- $n$-butyl phosphate : $\left.\left(\mathrm{C}_{4} \mathrm{H}_{8} \mathrm{O}\right)_{3} \mathrm{PO}\right)$, CMPO(Octyl (phenyl)- $N, N$-diisobutylcalbamoylmethylphosphine oxide : $\left.\mathrm{C}_{24} \mathrm{H}_{42} \mathrm{NO}_{2} \mathrm{P}\right)$ は, アクチニ ドに対する親和性が高く，Puと安定な錯体を形 成する ${ }^{(13)}$ 。CMPOは $\mathrm{Am}, \mathrm{Cm}, \mathrm{Np}$ 等マイナーアク チニドに対しても優れた抽出能を示すので，動燃 では CMPO/TBP混合抽出剤を用いた高レベル廃 液中のアクチニド核種の分離研究を行なってい る。CMPOは比較的新しい化合物であり，安全 性のみならず，一般物性についても公開された情 報量は極めて少ない。CMPOは分子内にホスホ リル基やフェニル基を有する有機リン化合物であ るので，本格的な使用に先立ちその生物学的な安 全性について確認することとした。

そこで新規化学物質の毒性を調べる上での常法 である急性毒性試験と, 発がん性・遺伝毒性の予 測に用いられている変異原性試験を予備的に実施 した。急性毒性については雄マウス群（５匹）に CMPO を経口および経皮投与し，14日間にわ 
たって状態を観察した。観察期間中，死亡例もな くいずれの個体も正常な体重增加を示した。本研 究では, 経口 $\mathrm{LD}_{50}$ 值 (50\%致死量) として $>3,000$ $\mathrm{mg} / \mathrm{kg}$ ，また経皮 $L D_{50}$ 值 $>2,000 \mathrm{mg} / \mathrm{kg}$ を得た。 変異原性は，サルモネラ菌を用いた復㷌突然変異 試験および枯草菌を用いた DNA 修復試験(スト リーク法)の両法で評価し，その結果はともに陰性 であった。急性経口毒性に関しては, $\mathrm{LD}_{50}$ 値が 30 $\mathrm{mg} / \mathrm{kg}$ 以下のものを毒物, $30 \sim 300 \mathrm{mg} / \mathrm{kg}$ の範 囲を劇物と見てよい。したがって, $\mathrm{LD}_{50}$ が 3,000 $\mathrm{mg} / \mathrm{kg}^{(14)}$ と報告されている TBP と同様, CMPO の危険性は極めて低く，普通物としての取扱が可 能との確証が得られた。

以上，Pu の安全性にまつわる基本的な物理化 学的性格と環境条件下における特徽的な挙動を紹 介した。併せて，新しい知見を基にアクチニド抽 出剈の生物学的安全性について若干言及した。 $\mathrm{Pu}$ を含むアクチニドの溶液化学・地球化学につい ての情報は，安全性ならびに環境浄化に対する関 心の高まりと研究動向に呼応して，今後いっそう 重要性を增すむのと考えられる。

\section{一至考献—}

（1）鈴木継美, 和田 功：“重金属中毒”，(1978），医歯
薯出版。

(2) KLEYKAMP, H. : "Nukleare Entsorgung", Band 2, p.151 166 (1983), Verlag Chemie GmbH, Weinheim.

(3) BlEYL, H. J. : ibid., p.141 149.

(4) METIVIER, H. : Radioprotection, 19[2], 115 128 (1984).

(5) Nenot, J.C., Stather, J.W. : "The Toxicity of Plutonium, Americium and Curium", Chap. 2, (1979), Pergamon Press.

(6) Scoazec, H., Pasquiou, J.Y., Germain, M. : Int. Chem. Eng. Symp. Series No. 119, (1990).

(7) KIM, J.I. : "Handbook on the Physics and Chemistry of the Actinides", Vol.4, (1986).

(8) Allard, B.: Proc. of Actinides-81 Conf., p.553 580 (1982), Pergamon Press, Oxford.

(9) RaI, D., Swanson, J. L. : Nucl. Technol., 54, 107 112 (1981).

(10) RaI, D., Serne, R. J., Moore, D. A. : Soil Sci. Soc. Am. J., 44, 490 495 (1980).

(11) Patterson, J. H., Nelson, G. B., Matlack, G. M., WATERBURY, G. R. : IAEA-SM-199/100，(1975).

(12) 天沼 倞, 村野 徹訳：“放射性廃棄物の地層処分に 関する地球化学プロセス”，(1982），テクノ・プロ ジェクト.

(13) Mathur, J. N., Murali, M. S., Natarajan, P. R., BADHEKA, L. P., BANERJI, A. : Talanta, 39[5], 493 496 (1992)

(14)“化学薬品毒性データ集成”，(1975)，海外技術資 料研.

\section{IV. プルトニウムの生体内挙動 と線量評価}

放射線医学総合研究所 高橋 千太郎

Puの生体内での挙動, 代謝ならびに線量評価に 関しては，主として動物実験から得られたデータ に関する論文や，それらをもとにした関係機関の 報告書が多く出版されている(1) (3)。また，我が 国においてむ，Puの安全性に関する優れた著書 がある ${ }^{(4)}$ 。本章では，国際放射線防護委員会 (ICRP)の出版物を中心に, Pu の生体内での挙動 と線量評価に関してその概要を紹介する。

\section{Puの摂取経路}

Puを摄取する経路としては, 飲食物とともに
摄取する経口摄取，皮虑を介して体内へ侵入する 経皮吸収(火傷や㓣傷部からの吸収を含む)，および呼 吸に伴う吸入摄取が考えられる。第 IV-1 図に, $\mathrm{Pu}$ の摄取経路とその後の生体内での挙動を模式 的に図示する。

\section{（1）释口摄取と消化管吸収率}

$\mathrm{Pu}$ を経口摂取すると，大部分は吸収されずに 荼中に排泄されてしまうが，ごく一部は胃や腸な どの消化管から吸収され，血液を介して骨や肝臓 へ沈着する。しかし，Puの消化管からの吸収率 は極めて小さいことが動物実験から明らかにされ ている。ICRPは，過去の多くの害験結果をもと に，作業者の被曝線量を算定するための $\mathrm{Pu}$ の消 化管吸収率を，放射線防護上，酸化物(多分散の屯 のを除くでは $0.001 \%$, 硝酸塩0.01\%，その他0.1\% とするように勧告している。ちなみに, ${ }^{131} \mathrm{I}$, トリ 


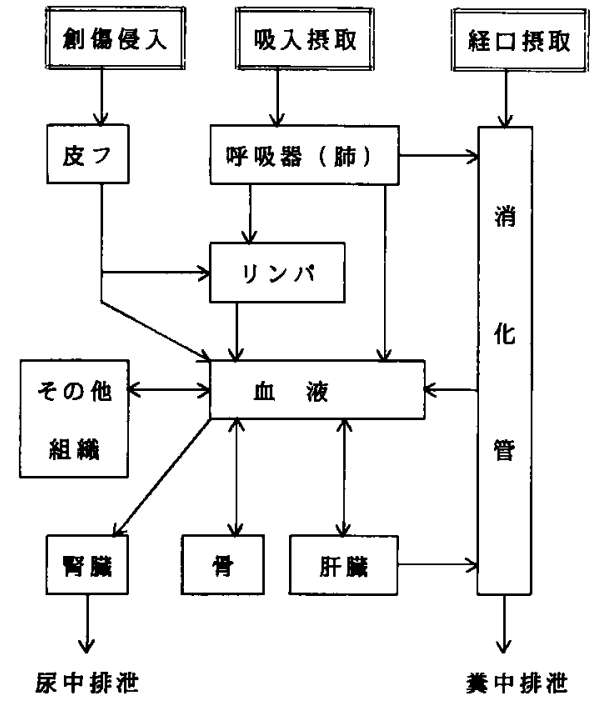

第 IV-1 图 $\mathrm{Pu}$ の攝取経路と生体内での挙動の概要

チウムは $100 \%,{ }^{60} \mathrm{Co},{ }^{90} \mathrm{Sr}$ は $30 \%$ と勧告されてお り，Puが極めて消化管から吸収されにくい元素 であることがわかる。

このようにPuの消化管からの吸収率はかなり 低く，また原子力施設などの放射線管理区域では 飲食が禁止されているため，Puの経口摄取は贈 業被曝を考える際には重要ではない。しかし，環 境中の極低レベルのPuを経口的に摄取する可能 性がある一般公衆の場合，長期的に $\mathrm{Pu}$ を継続し て摄取する可能性があること，摄取される $\mathrm{Pu} の$ 量が少なくなるほど消化管吸収率が上昇するこ と，消化管吸収率の高い幼若児が集団に含まれる こと等の点から，経口摄取に伴う消化管吸収率の 推定は重要な問題である。

経口摄取され，消化管から吸収されたPuは， 血液中へ移行し，その後，次節に述べるように， 主として肝缄や骨に沈着する。

（2）経皮吸収上創体侵入

環境中の毒性物質の中には，皮店から吸収され て，人体に障害を与えるものああるが，Puは一 般に健常な皮虔からはほとんど吸収されない。た だし，皮店に炎症や火傷のある場合や，組織唚透 性の高い特殊な有機溶媒に溶解されているといっ た場合には経皮的に吸収される。したがって，
$\mathrm{Pu}$ の経皮吸収として問題になるのは, 炎症や創 傷により皮唐が正常な障壁としての機能を失って いる時や，高温のすのや化学薬品による火傷と同 時にPuで污染されたときなどの特殊な場合に限 られる。また, 金属PuやPuで污染された器具に よる創傷によって皮下や筋肉が污染される事故は 多く報告されており，このような場合は，外科的 な手術によって除去されることも多い。

経皮吸収や創傷によって体内に侵入したPuは, 硝酸プルトニゥムのようなイオン状のあのであれ ば, 比較的速やかに血液中へ移行し, 難溶性のも のであれば，創傷部位に長期間滞留し，一部はリ ンパ管へ移行したのち、リンパ節に長期に滞留す る。

\section{（3）吸入预取と呼吸器での挙動}

Puが空気中に微細な粒子(エアロソル)として存 在すると, 呼吸に伴い吸入され呼吸器に沈着す る。しかし，吸入された粒子の全量がそのまま肺 へ沈着するのではなく，一部は呼気と共に体外へ 吐き出される。吸入された放射性粒子の呼吸器へ の沈着率やその後の動きについては, ICRPの呼 吸器モデルに詳しく述べられているが，一般に粒 子径が大きな粒子は，鼻，咽頭，哄頭などの上部気 道に多く沈着し，粒子径が小さくなるに従って肺 の深部に沈着する率が高くなる。例えば，100個 の粒子を吸入した之仮定し，ICRP の呼吸器モデ ル(1)に示された沈着率をもとに計算すると，粒子 の空気動力学的な径が $5 \mu \mathrm{m}$ であれば，およそ75 個が鼻咽喉頭部に，8個が気管・気管支部に，8 個が肺の深部に沈着し，残り 9 個は沈着しないで 呼気と共に排出される。粒子径が $0.2 \mu \mathrm{m}$ になる 之, 鼻咽喉頭部へ 5 個が, 気管·気管支部へは 8 個が，肺の澡部へは50個が沈着し，残りの37個は 呼気中に排出される。このように, 呼吸器への沈 着率や呼吸器各部への局所沈着率は，吸入粒子の 径に大きく依存しており，したがって，Puの吸 収摄取による内部被曝の影響を考えるときは， $\mathrm{Pu}$ エアロゾルの化学形だけでなく，その粒子径 についての情報が重要である。

吸入によって呼吸器に沈着したPuのうち，鼻 咽喉頭部や気管·気管支部へ沈着したものは,「た ん」として速やかに消化管へ排泄される。一方， 
肺の深部に沈着した場合は，Pu粒子の化学形に よってその後の挙動は大きく異なり, 酸化プルト ニウムのような難溶性の粒子として吸入された時 は, 肺の深部に長期に滞留する。一方, 溶液状ま たは溶解性の高い粒子として吸入されたときは, 比較的速やかに体内に吸収され，血液を介して肝 臟や骨に移行, 沈着する。

\section{Puの生体内での挙動}

\section{（1）血液中での存在状態と藏器への沈着}

上記の摄取経路を介して血液やリンパに移行し た Puは，イオン状の場合は, 主としてグロブリ ンや鉄輸送タンパク質であるトランスフェリンと 結合した状態で体液中に存在する。一方, 体液中 で水酸化物重合体となったPuは，コロイド状物 質として体液中に存在し，その後の挙動は粒子状 物質としての特徴を呈する。タンパクに結合した $\mathrm{Pu}$ は, $\mathrm{Pu}$ と親和性の高い糖タンパクを多く含む 肝臟や骨に到達すると，その部位で血液中の結合 タンパクから解離し、これらの臓器に蓄積する。 一方, コロイド状の重合体として血液中に存在す る Puは, 肝臓や骨䯣中の網内系細胞に取り込ま れ，これらの部位に蓄積される。一般に，血液中 へ移行したPuの $90 \%$ 程度は骨と肝臓に沈着し， 沈着初期における存在比(骨：肝埛)は攝取経路や 化学形, 動物種によって異なるが, ICRP は線量 計算を行うにあたって $1: 1$ を使用している。

$\mathrm{Pu}$ は特異的に骨に集中して沈着する元素であ り，しばしば骨親和性核種と呼ばれる。Puの骨 での分布は，RaやSrなどが骨の実質(つまり骨全 体）拡散して分布するのに対し，骨の内外の表 面に限局して存在するのが特徽である。

肝葴扔よび骨以外にPuが特異的に高濃度で蓄 積する蔵器は認められていない。遺伝的影響の点 から関心のあたれている卵巣や精巣への移行沈着 率も，遺伝的な影響が危惧されるほどには高くな いことがわかっている。

\section{（2）各蔵器からの消失上体外への排泄}

鼻咽喉頭部や気管·気管支部といった上部呼吸 気道に沈着した Puは，気道の粘液と絨毛の働き によって比較的速やかに消化管へと除去され，霬 便中に排泄される。これに対し，呼吸器深部に沈
着した $\mathrm{Pu}$ のこの部位からの消失速度は遅く, 酸 化プルトニウムなどでは数100日の半隇期である。

肝臟に沈着した $\mathrm{Pu}$ は，一部は胆汁を経由して 䔬便中に排泄されるが，その排泄速度は小さく， ICRP では標準值として半滅期を20年としてい る。骨に沈着したPuも，長期にこの部位に滞留 し骨腫瘍などの原因となる。ICRPは骨からの Pu の消失に関し, 標準值として半減期50年を提唱し ている。血液中の $\mathrm{Pu}$ は，前述のように，そのほ とんどが肝臟と骨に沈着するが，一部は腎臓から 尿中へ排泄される。ただし，尿中排泄量は一般に 䔬便中に排泄される量より少ない。

\section{Puの捸取による線量}

$\mathrm{Pu}$ の身体内での分布とその経時的な変化，各臓 器の幾何学的な位置や質量, Pu の同位体組成(放 射線の種類とエネルギー)等の情報をもとに，Pu摄 取に伴って各葴器や全身が受ける線量を算定する ことができる。ICRPは，生体内での放射性物質 の挙動をモデル化し線量算定に使用するため，呼 吸器モデル, 骨モデル, 消化管モデルを提唱してい る。また, 人体臟器の位置や重量等に関しては標 準人を策定して，放射線防護の目的での線量評価 を可能にしている。本節では,このような線量算 定の過程の詳細は誌面の関係で省略し, 線量評価 の最終的な目的ともいえる「Puを摄取したら一生 涯にどれぐらいの放射線量を受けるのか」につい て述べる。

\section{（1）預託等価線量亡預託実效線量}

初めにICRP が勧告している預託等価線量と預 託実効線量について簡単に説明する。放射線被嚗 の程度を示す「線量」には，いくつかの表わし方が あるが，基本的な尺度の 1 つは吸収線量である。 吸収線量は単位質量 $(\mathrm{kg})$ 当りに吸収されたエネル ギー(J)で表わされ，単位はグレイ(Gy)である。 吸収線量に線質を表わす放射線荷重係数を乗じて 得られる線量は等価線量と呼ばれる。これによっ て線質の異なる被曝, 例えば $\gamma$ 線による被曝之 $\alpha$ 線による被曝を比較することができるようにな る。さらに，不均等な被曝之均等な全身照射の比 較を可能にするため, 臓器・組織の放射線感受性 の相対值で荷重した等価線量を被曝したすべての 
臓器・組織で加算した実効線量が提唱されている。 実効線量を用いることで，Pu の内部被曝のよう に不均一な照射によって受ける損害が $\gamma$ 線の全身 均一照射のどの程度の線量に相当するかを知るこ とができる。

ICRPはさらに，内部被曝では，体内に入った 放射性核種が体内から排泄されるか, 物理的半減 期で減哀するまでの時間にわたって被曝を受け続 けることから，預託等価線量および預託実行線量 を補助的な線量計湘値として使用することを推奖 している。これらの線量は，当該放射性核種を摂 取してから公衆では70歳に達するまでに受けるで あろう等価線量または実効線量の積算値と定義さ れている。

\section{（2） Pu 摄取時の預託等価線量亡 預託実効線量}

ICRP Publ. 56 には，種々の年齢で $1 \mathrm{~Bq}$ の Pu を摄取したときの預託等価線量と預託実効線量 （線量換算係数と呼ばれる）が勧告されている。一例 として, 第 IV-2 図に, ${ }^{239} \mathrm{Pu}$ (クラスY,酸化プルト ニゥムのような肺からの消失が荤いるの)を 3 力月齢, $1 ， 5 ， 10 ， 15,20$ 歳に吸入によって $1 \mathrm{~Bq}$ 摂取した 場合の肺, 肝臓, 骨表面における預託等価線量之預 託実行線量を示す。

図からわかるように，吸入摄取時の年齢が若い ほど預託実効線量は大きくなる。肺や肝臓におけ る預託等価線量も年龄によって異なっている。こ れに対し，骨表面の預託等価線量は摄取時の年齢 の影響を余り受けない。より肺から消失しやすい

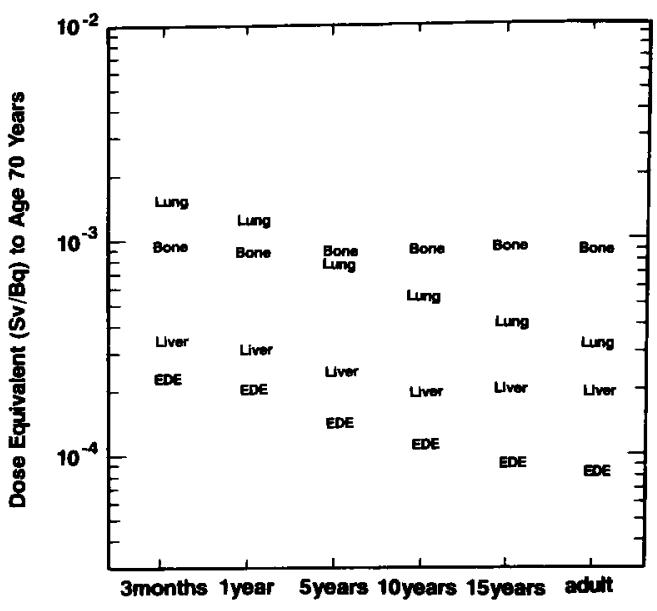

第 IV-2 図種々の年齡で $\mathrm{Pu}$ (クラス Y)を $1 \mathrm{~Bq}$ 吸 入したときの主要臓器における預託等 価線量ならびに預託実効線量

Lung, Bone, Liver は，それぞれ肺， 骨表面および肝脿における預託等価線 量(線量換算係数)を，EDE は預託実 効線量を示す。

$\mathrm{Pu}$ 化合物 (クラスY)や経口摄取時の計算値 あ同報 告書に記載されているので参照されたい。

\section{一参考文献—}

(1) ICRP Publ. 30, (1979), Pergamon Press, Oxford.

(2) ICRP Publ. 48, (1986), Pergamon Press, Oxford.

(3) ICRP Publ. 56, Part 1, (1989), Pergamon Press, Oxford.

(4) 松岡 理：“プルトニウムの安全性評価”, (1993), 日刊工業新聞。

\section{V. プルトニウムの生物影響 動物実験とそのリスク}

放射線医学総合研究所 小木兽 洋一

\section{1.はじめに}

$\mathrm{Pu}$ の身体的影響とそのリスクについては，人 体実験例を含めて，その因果関係を明確に示すよ うな人体データがないので, 動物実験によって得 られたデータから推定する以外にない。これまで に米国を中心に諸外国で行われてきた多くの動物
実験の成果加ら, Pu の生物学的影響は, 消化管 を介しての摄取・吸収ではなく，ほとんどが呼吸 器を介しての吸入や創傷等皮唐吸収を介しての血 液移行によってもたらされること，また致死等急 性障害のリスクよりも，発がん，寿命短縮等晚発 障害のリスクが重要であることが知られている。 また近年，英国セラフィールド核施設作業者の子 供における白血病, リンパ腫多発の調查報告(1)に 見られるように，遺伝的影響と継世代的影響ある いは胎児被曝のリスクについてす生物学的影響の 対象として重要視されている。 
本章では, 我々の行なっている実験例について あ一部紹介しつつ, 動物実験によるPuの発がん 性について, リスクの対象を骨, 肺, 肝臓等軟組織 や造血組織それぞれについて概説し，最後に胎児 への影響や遺伝的影響のリスクについてす触れる ことにする。

\section{Puによる骨腫瘍とそのリスク}

$\mathrm{Pu}$ は骨親和性核種であるので，血液に入った 後, 肝葴など網内系組織にも一部沈着するが, 最 終的には骨組織の骨内膜表面に沈着し, 徐々に骨 基質内ミネラルに埋め込まれてゅく。この沈着・ 埋込過程で周囲の骨芽細胞が $\boldsymbol{\alpha}$ 線照射をうけて変 異し，やがて腫瘍化すると考えられている(2)。こ うして生じた骨腫痬の大部分は, 悪性度, 浸潤度 の強い骨肉腫であるが，投与量あるいは骨吸収線 量と骨肉腫誘発率との関係や，ヒトに外挿するた めに必要な生物学的パラメータのうち重要な動物 種差と毒性比に関しては，すでに米国ユタ大学の 研究グルーブが行なったビーグル犬等を用いた生 涯実験により，明らかにされている(3)(4)。

これによると，Pu( ${ }^{238} \mathrm{Pu}$ および $\left.{ }^{239} \mathrm{Pu}\right)$ は ${ }^{90} \mathrm{Sr}$ など $の \beta$ 線放出核種はすちろんのこと， $\alpha$ 線放出骨親 和性核種である ${ }^{226} \mathrm{Ra} や{ }^{241} \mathrm{Am},{ }^{244} \mathrm{Cm}$ 等,その他の 超ウラン元素に比べて最大の毒性(すなわち ${ }^{226} \mathrm{Ra}$ による骨肉腫誘発線量と比較して約16倍の相対リスク) を有し，しきい值のない直線的線量勃果関係を示 すが，この毒性比には動物種差が比較的少ないの で, ヒトでのリスク推定が可能なモデルとして有 用なデータを提供している。また，Puによって 誘発される骨肉腫の好発部位については, 骨梁骨 が豊富で、ミネラル骨のリモデリング率が高く,か つ造血組織である骨䯣における幹細胞および微小 血管構築の豊富な椎骨, 胸骨あるいは上腕骨, 大腿 骨など四肢骨に特に多発すること蛙(5)が示されて いるが，我々のマウスヤラットを用いた実験です 骨肉腫は椎骨, 四肢骨に多発し, 頭蓋骨など骨䯣組 織や骨梁の発達の乏しい骨には見られていない。

腫瘍細胞の発育・浸潤性を修飾するこのような 生体要因に関する情報はまだ十分とはいえない が, 骨腫痬のみならず後述する白血病誘発のメカ ニズムとの関係でも興味ある内容を含んでいると
思われる。なお, Pu同位体のうち, ${ }^{238} \mathrm{Pu}$ は ${ }^{299} \mathrm{Pu}$ に比べて比放射能が大きく，酸化物も溶解性が高 いので, 吸入被曝のような経路でも速やかに血液 移行しやすく，したがって骨肉腫を誘発しやすい ことが知られている(6)(7)。

\section{Pu 微粒子吸入による肺腫瘍と そのリスク}

$\mathrm{Pu}$ は, 原子力施設等で取り扱われる場合, 摂 取経路として吸入による被曝の可能性が高いの で, 微粒子(エアロソル)の吸入によって生じる肺 腫瘍とそのリスクについて, 多くの実験研究がな されてきた。その代表的なあのは，米国 PNL (Pacific Northwest Laboratory)および ITRI (Inhalation Toxicology Research Institute)のグループ によって行われたラットあるいはイヌを用いた生 涯発がん実験である。PNLのSandersらは,主に ラットを用いて, 吸入性酸化プルトニウム微粒子 の肺腫痬誘発性について, 高温あるいは低温焼結

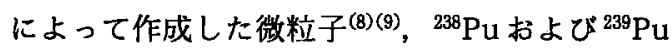
酸化物 ${ }^{(8)(10)}$ ，または ${ }^{241} \mathrm{Am},{ }^{244} \mathrm{Cm}$ 酸化物 ${ }^{(11)(12)}$ 等 の比較により, 酸化プルトニゥム(特に $\left.{ }^{239} \mathrm{Pu}\right)$ の高 温焼結微粒子の高発がん性と動物種差などを詳細 に検討しているが, その場合，酸化物の凝集によ る肺組織内短細分布の不均等性之長期滞留が, 重 要な発がん修飾要因のひとつであることを示すと とあに ${ }^{(13)}$ ，最近になってまとめた ${ }^{239} \mathrm{Pu}$ 酸化物に よるラットの生涯発がん実験データの解析から, 線量効果関係には“実際的なしきい值”の存在す ることを提唱している(14)。すなわち，肺吸収線 量として 1Gy以下の線量では, 対照(非吸入群)に 比べて, 生存率および肺腫瘍発生率に差がみられ ず，実際には $2 \mathrm{~Gy}$ 以上で有意差がみられるとい うあのである。

しかしながら, 我々が現在行なっている ${ }^{239} \mathrm{Pu}$ 酸化物微粒子のラットへの吸入実験の中間段階で の結果からは, 1〜2Gy の比較的低線量域でも肺 腫瘍の有意な発生が予想され，1Gy以下の極低 線量域の線量効果関係の詳細についてはまだ検討 を要するすのと思われる。一方，イヌを用いた Pu吸入による肺腫崲についても，PNLの他の研 究グループによる生涯発がん実験から，ほぼ直線 
的な線量効果関係が示されているが，低線量域で の発がん率やしきい值の有無等についての詳細な 結果はまだ明らかでない。最も重要な成果は, 肺 腫瘍誘発の化学形による差であろう ${ }^{(15)}$ 。すなわ ち，比放射能，溶解性の異なるPuの高温粠結酸化 物 ${ }^{238} \mathrm{PuO}_{2}$ と $\left.{ }^{239} \mathrm{PuO}_{2}\right)$ 並びに溶解性の高い ${ }^{239} \mathrm{Pu} の$ 硝酸塩 $\left.{ }^{239} \mathrm{Pu}\left(\mathrm{NO}_{3}\right)_{4}\right)$ をそれぞれイヌに吸入させる と, 肺組織内における滞留率, 気管支リンパ節, 肝 臓への移行率さらに最終的な骨組織への沈着率は それぞれ異なるため, 結果的に誘発される肺腫痬 発生率は溶解性の低い ${ }^{239} \mathrm{PuO}_{2}$ で最大であり, 逆 に骨腫演発生率は ${ }^{238} \mathrm{PuO}_{2}$ および ${ }^{239} \mathrm{Pu}\left(\mathrm{NO}_{3}\right)_{4}$ でむ しろ大きいことが明らかとなった。

また気管支リンパ節への再沈着による末梢血り ンパ球数の著減や後述する肝の腫瘍性病変の出現 率などあこのような化学形の差をほぼ反映したも のとなっている。また，吸入性微粒子の肺腫湢誘 発性を修飾する要因のなかで重要なすのは，化学 形のみならず粒子径の差であり, ITRIのグルー プはPuだけでなく，溶解性，血液移行の異なる ${ }^{144} \mathrm{Ce}$ 等 $\beta$ 線放出核種の微粒子をそれぞれ空気動力 学的中央径(AMAD)の異なる単分散エアロゾルと してイヌに吸入し, 滞留率, 移行率, 線量率および 生涯発がん率の比較実験を行なっているが(16), 粒子径の異なるPuの発がん率の差についてはま だ明らかなデータが公表されていない。

プルトニウム酸化物の吸入によって誘発される 肺腫瘍発生のリスク推定には，上述した線量効果 関係のみならず，標的細胞の決定とそれに対する 微細線量および生物反応の評価が必要である。誘 発腫瘍の組織型は, 主に細気管支-肺胞部由来の 腺がんあるいは腺扁平上皮がんであることから， 下部呼吸気道被覆細胞が標的であることが想定さ

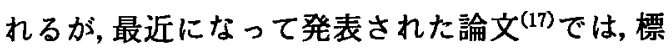
的細胞が肺胞上皮細胞あるいは終末細気管支上皮 細胞であり,そこに生じた增殖と腫瘍性変化に至 る過程などが明らかにされており,さらに標的細 胞レベルでの線量の寄与および腫瘍性変異発現型 との関係についての解明が必要となるであろう。

\section{4. その他軟組織腫瘍とそのリスク}

$\mathrm{Pu}$ によって誘発される腫瘍とそのリスクは,
上述した骨肉腫および肺腫瘍が最す重要である が, 実験的に観察されているその他の腫瘍とし て, 肝臓腫瘍,リンパ腫あるいは白血病など造血 組織等軟組織腫瘍があり，これらについても考虑 される必要がある。このうち肝臓腫瘍について は, Puが沈着しやすく，かつ付与される線量が 骨線量よりも高いことなどから，そのリスクが提 唱されてきたが，実際に様々な動物種で，また注 射あるいは吸入など被曝形式の差や，他の $\alpha$ およ び $\beta$ 核種との比較による実験 ${ }^{(18)(19)}$ 等から推定さ れる肝臓原発の腫瘍発生のリスクはPuでは, そ れほど大きくないと考えられており，また実質細 胞の腫瘍である肝細胞がんよりは，胆管がん，線 維肉腫あるいは血管肉腫等非実質細胞腫演の割合 が多い。それは組織内沈着部位と標的細胞の放射 線感受性の差を反映しているすのと思われる。

一方，Puは骨梁骨扔上び骨内膜表面に沈着し， 骨細胞のみならず造血組織である骨䯣幹細胞にも $\boldsymbol{\alpha}$ 線照射が及ぶため，造血細胞の腫演である白血 病, 骨䯣腫あるいはリンパ腫の発生リスクについ ても明らかにされる必要がある。実際にマウスで は, 骨肉腫誘発に必要な線量よりあ高い線量域 で, リンパ腫およびリンパ性白血病が多発するこ とが我々の寒験および他のグループの実験からも 示されている(20)。しかし, 骨䯣性白血病について はやはりマウスで, 骨肉腫誘発線量よりはるかに 低い線量域でのみ, わずかながら増加することが 報告されているのみで, 他の $\alpha$ 核種に比べると, そのリスクは小さく(21), ラットやイヌ等その他の 動物種であ明らかな有意差はみられていない(22)。

また，低レベルのPu注射による骨䯣幹細胞数 の減数(23)(24) あるいはPuの $a$ 線を照射した骨䯣細 胞およびリンパ球でみられる高い染色体異常と突 然変異誘発率など(25)(26), 標的細胞レベルでの初 期変化を示すデータも多いが, リンパ腫や白血病 誘発との関係はまだ明らかではない。

\section{5. 胎児被䀧およひ通伝的影雾のリスク}

胎児被曝のリスクについては，妊娠動物に注射 された Puが子宮胎盤を介して胎児組織にまで到 達する割合は極めて少ないあのの，造血幹細胞の

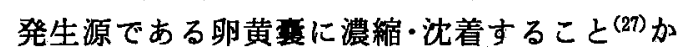


ら, 出生前のみならず出生後の生物影響について も注目されている。最近の研究から，マウス胎児 では卵黄襄のみならず，骨䯣造血開始前に造血幹 細胞の増殖·分化が活発に行われている肝蔵にお いて，Puは母体の骨に比べて高い濃度の沈着と 線量付与がみられ, 出生後の多能性造血幹細胞は ほぼ 1 年の長期にわたって减少し，その RBE (relative biological effectiveness)は $\gamma$ 線に比べて従 来考えられていたよりあはるかに大きいとする結 果が得られている(28)。このことは，前述の Pu 注 射個体での造血幹細胞の持続的減少 ${ }^{(23)(24)}$ 之類似 の生物効果であるが, 最終的に白血病等晚発障害 に結び付くあのかどうかは明らかではない。

生物学的影響の中で重要なむのとして, 生殖細 胞に起こる染色体異常および遺伝子突然変異のよ うな遗伝的影響がある。これはその個体では発現 することはなくても，その子孫に受け継がれ，発 がん等重篤な影響として発現する継世代的影響に 結び付く可能性をあつ。Puは, 生殖器とくに精 宩組織の間質に比較的高濃度に沈着し, 生殖細胞 染色体および遺伝子に対する $\alpha$ 線線量がかなり大 きいので, 染色体異常の起こる確率が高いこ と ${ }^{(29)}$ が知られており，遣伝的影響と継世代的影 響の発生リスクについてあ考慮されるべきである が，実際にそのことを証明する実験はまだなされ ておらず，今後の重要研究課題のひとつである。

\section{6.おわりに}

以上, $\mathrm{Pu}$ の生物学的影響とそのリスクについ て, 諸外国で行われた動物実験による発がん効果 を中心に概略を述べたが，人体影響のリスクを推 定するためには，線量効果関係の解析法む含めて 末解決の問題が多く残されているように思われ る。また，胎児に対する影響や遺伝的影響につい てはほとんどわかっていない。発がんも含めて Puによる内部被曝の確定的あるいは確率的影響 に関する動物を用いた実験的研究がさらに発展・ 推進されるべきであろう。同時に，本章では詳し く紹介しなかったが，リスクの対象となる細胞あ るいは染色体·遗伝子レベルでの $\alpha$ 線照射とその 影響発現についても，低LET 放射線と比較して の生物学的効果比の検討を中心に, 研究が進んで
おり，個体レベルでのリスク評価を補完し，また その精度を向上するためにも重要な情報を提供す るすのと考えられる。

\section{一参考文献—}

(1) GARDNER, M. J., et al.:Brit. Med. J., 300, 423 429 (1990).

(2) WRONSKI, T. J., et al.: Radiat. Res., 83, 74 89 (1980).

(3) TAYLOR, G. N., et al. : ibid., 95, 584 601 (1993).

(4) MAYS, C. W., et al. : Life-Span Radiation Effects Studies in Animals : What Can They Tell Us? (ed. Thompson, R. C., Mahaffey, J.A.), CONF830951, p. 229 310 (1986).

(5) MILLER, S. C., et al. : ibid., p. 286 298.

(6) HAHN, F. F., et al. : J. Natl. Cancer Inst., 67, 917 927 (1981).

(7) Muggenburg, B. A., et al. : Health Phys., 44, 529 535 (1983).

(8) SANDERS, C. L., et al. : Radiat. Res., 68, 349 360 (1976).

(9) SANDERS, C. L., MAhaffey, J. A. : Int. J. Radiat. Biol., 35, 95 98 (1979).

(10) SANDERS, C. L., et al. : Radiat. Res., 71, 528 546 (1977).

(11) SANDERS, C. L., MAhaffey, J. A. : ibid., 94, 66 80 (1983).

(12) SANDERS, C. L., MAHAFFEY, J. A. : ibid., 76, 384 401 (1978).

(13) SANDERS, C. L., et al.: ibid., 116, 393 405 (1988).

(14) SANDERS, C. L., et al. : Int. J. Radiat. Biol., 64, 417 $\sim 430$ (1993).

(15) PARK, J. F., et al. : Ref. (4), p. 455 470.

(16) McClelLAN, R. O., et al.: ibid., p. 74 96.

(17) HERBERT, R. A., et al. : Radiat. Res., 134, 29 42 (1993).

(18) TAYLOR, G. N., et al.: Health Phys., 64, 141 146 (1993).

(19) TAYLOR, G. N., et al.: Ref. (4), p. 268 285.

(20) Loutit, J.F., CARR, T.E.F. : Int. J. Radiat. Biol., 33, 245 263 (1978).

(21) HuMphreYs, E. R., et al. : ibid., 51, 331 339 (1987).

(22) TAYLOR, D. M. : Ref.(4), p. 404 412.

(23) SHOFiELd, R., et al.: Int. J. Radiat. Biol., 49, 1021 $\sim 1029$ (1986).

(24) SvoBoda, V., et al. : ibid., 52, 517 526 (1987).

(25) KADHIM, M. A., et al. : Nature, 355, 738 740 (1992).

(26) PURRotT, R. J., et al. : Int. J., Radiat. Biol., 38, 277 $\sim 284$ (1980).

(27) Morgan, A., et al. : ibid., 59, 1395 1413 (1991).

(28) JIANG, T. -N., et al. : Radiat. Res., 137, 380 384 (1994).

(29) BRooKs, A. L., et al. : ibid., 77, 292 302 (1979). 


\section{V. 人体での観察}

放射線医学総合研究所 稲 葉 次 郎

$\mathrm{Pu}$ の毒性学に関しては, 相当程度の動物実験 が行われてきたことはすでに述べたところである が，それらすなわちPuの生体内動態と生物学的 影響に関し人体例で観察した報告はあまり多くな い。松岡(1)によれば，これまでに報告された $\mathrm{Pu}$ に污染された人体の観察例は以下の 6 例がある。

すなわち，(1)マンハッタン計画Pu作業員，(2) Pu投与末期がん患者, (3)ロッキーフラット火災 事故被曝者, (4)米国超ウラン登録患者，(5Pu 創 傷摄取作業者，(6)中国でのPu取扱作業者である。

(1)(4)については後述するが，(2)は人体実験とし て最近になっても時に新聞等で取り上げられる問 題であり，放射線科学 ${ }^{(2)} ゙$ あ紹介されている。

(3)1965年10月に，米国ロッキーフラット核兵 器工場で発生した火災の折に多数の作業者が種々 のレベル(平均值で $65 \mathrm{~Bq}$ と低レベル)の酸化プルト ニウムを吸入した事故であり，吸入したであろう $\mathrm{Pu}$ の粒子径が測定されていて，健康影響の追跡 調査結果が興味深いところであるが，1979年まで しか追跡調查 ${ }^{(3)}$ 赫告されておららず，肺がん，骨 がん, 肝がんにおいて有意の增加はみられていな い。

(5)は病理学者による報告(4)であり，創傷侵入し た $\mathrm{Pu}$ 金属片周包の組織学的検索の結果，前がん 性の上皮の組織学的変化が見られたとしている。

(6)は中国からの新しい報告(5)で興味深いが，今 後の追跡調查が待たれる。

上記のような報告の中から，本章では，Puの 人体への生物学的影響の例として(1)を，また体内 代謝として(4)を取り上げる。これらを選んだの は，他に比へてて比較的しっかりした体制で追跡調 查が行われていると考えられるからである。

\section{1. マンハッタン計画に従事した} Pu作業員の追跡調查

第 2 次世界大戦の中，すなわち1944年から45年 にかけて米国ロスアラモスでマンハッタン計画に 従事し，Puを主として吸入により体内に取り込
んだ若い化学者26人について, Voeltzらによる 詳細な追跡調查が報告されている(6)。Pu体内量 の推定は，例外的な体外計測を除けば，すべてが 尿中放射能を計測するというバイオアッセイ法に より行われている。尿中放射能と体内量との関係 は当初, 前述の(2)Pu投与末期がん患者での観湘 結果等を基にしたLangham の関係式が用いられ たが，追跡の過程での死者の剖検試料分析の結果 なども参考にしながら，数次にわたり関係式の改 訂が行われている。

報告されている最新のデータは1987年に推定し た値で第 VI-1 表に示す。個人の值は $52 \mathrm{~Bq}$ から $3,180 \mathrm{~Bq}$ までで，平均値は $500 \mathrm{~Bq}$ である。これ ら26人のうち1990年までに 7 人が死亡している。 死者に関するデー夕を第 VI-2 表に示す。7 件の 死亡のうち，肺がんが 2 例，心筋梗塞, 動脈硬化

第 VI-1 表 Pu 沈着量の推定値

\begin{tabular}{|c|c|c|c|c|}
\hline \multirow{2}{*}{$\begin{array}{l}\text { 標識 } \\
\text { 番号 }\end{array}$} & \multicolumn{2}{|c|}{ 推定 $\mathrm{Pu}$ 沈着量 } & \multirow{2}{*}{\multicolumn{2}{|c|}{$\begin{array}{c}\text { 総暴露 } \\
\mathrm{GBq}-\mathrm{s}(\mathrm{nCi}-\mathrm{yr}) \\
1987\end{array}$}} \\
\hline & $\begin{array}{c}\mathrm{Bq}(\mathrm{nCi}) \\
1987\end{array}$ & $\begin{array}{c}\mathrm{nCi} \\
1982 \\
\end{array}$ & & \\
\hline 7 & $3,180(86)$ & 62 & $2,710(2$ & $, 320)$ \\
\hline 3 & $2,550(69)$ & 95 & $5,480(4$ & $, 690)$ \\
\hline 4 & $2,150(58)$ & 63 & $3,810(3$ & $, 260)$ \\
\hline 9 & $2,000(54)$ & 40 & $3,540(3$ & $, 030)$ \\
\hline 8 & $1,780(48)$ & 34 & $1,280(1$ & $, 100)$ \\
\hline 5 & $1,630(44)$ & 55 & 3,670 (3 & ,140) \\
\hline 1 & $1,590(43)$ & 51 & $2,460(2$ & , 110) \\
\hline 6 & $1,590(43)$ & 42 & $2,250(1$ & ,930) \\
\hline 17 & $1,260(34)$ & 34 & $2,250(1$ & ,930) \\
\hline 18 & $1,110(30)$ & 33 & $1,910(1$ & $, 640)$ \\
\hline 16 & $670(18)$ & 7 & $383 C$ & 328) \\
\hline 12 & $560(15)$ & 18 & $1,020 C$ & 876) \\
\hline 10 & $520(14)$ & 14 & 975( & 835) \\
\hline 20 & $480(13)$ & 39 & 859( & 736) \\
\hline 11 & $480(13)$ & 11 & 882( & 755) \\
\hline 19 & $410(11)$ & 10 & $648 C$ & $555)$ \\
\hline 15 & $370(10)$ & 10 & $218 C$ & 187) \\
\hline 24 & $370(10)$ & 11 & 499( & 427) \\
\hline 21 & $370(10)$ & 8 & 514( & $440)$ \\
\hline 23 & $310(8.3)$ & 8 & 556( & 476) \\
\hline 22 & $290(7.9)$ & 8 & 230( & 197) \\
\hline 27 & $270(7.4)$ & 7 & 371( & 318) \\
\hline 2 & $270(7.2)$ & 8 & 379( & 325) \\
\hline 25 & $180(4.8)$ & 3 & 182( & 156) \\
\hline 26 & $110(3.0)$ & 4 & $148 C$ & 127) \\
\hline 13 & $52(1.4)$ & 2 & 65( & 56) \\
\hline 中央値 & $500(13.5)$ & 12.5 & $870 C$ & 745) \\
\hline
\end{tabular}


第 V-2 表 1990年までに死亡した人のデータ

\begin{tabular}{|c|c|c|c|c|c|}
\hline \multirow{2}{*}{$\begin{array}{l}\text { 標識 } \\
\text { 番号 }\end{array}$} & \multirow{2}{*}{$\begin{array}{l}\text { 死亡時 } \\
\text { 年 战命 }\end{array}$} & \multirow{2}{*}{ 死亡年 } & \multirow{2}{*}{ 死 因 } & \multicolumn{2}{|c|}{$\mathrm{Pu}$ 体内量 $\mathrm{Bq}(\mathrm{nCi})$} \\
\hline & & & & 死亡時 & 最大 \\
\hline 15 & 36 & 1959 & 心筋梗塞 & $370(10)$ & $590(16)$ \\
\hline 16 & 52 & 1975 & 交通事故 & $670(18)$ & $670(18)$ \\
\hline 27 & 62 & 1982 & 肺炎/心不全 & $260(7)$ & $780(21)$ \\
\hline 10 & 71 & 1985 & 肺がん & $520(14)$ & $1,150(31)$ \\
\hline 25 & 70 & 1988 & 心澸病(肺がん) & $150(4)$ & $410(11)$ \\
\hline 3 & 66 & 1989 & 肺がん & $2,550(69)$ & $6,960(188)$ \\
\hline 20 & 66 & 1990 & 骨のがん & $560(15)$ & $740(20)$ \\
\hline
\end{tabular}

症心臓疾患(肺がんもあった), 交通事故, 肺炎と充 血性心不全による呼吸障害および仙骨の骨肉腫各 1 例である。なお, 死亡者の中に 3 例の皮膚がん が見つかり，治療が行われていた。

26人という集団が放射性物質による健康影響に 関する疫学の対象としては余りに小さいというこ とは明らかであるが，全死亡に関しては米国全体 での年齢修正標準死亡率よりる低く，いわゅる 「健康労働者効果」が 42 年間の追跡の結果にも見ら れることが印象的である。がんの発生数は自然発 生数の変動の幅に入るすのであった。また, Voeltzらによって行われた別の研究(7)によれば, 1974年の時点で $370 \mathrm{~Bq}$ 以上の肺沈着量を示した 作業者の追跡調查の結果, 最後の調査までのその コホートの死亡数は 43 人で, 全米国民標準死亡率 から導かれる数の77人より少なく，そのうちがん による死亡数は 8 人で標準死亡率のそれは 15 人で あった。これらから，これらの作業者ではPuを 摂取したこととがん誘発の間にはなんら有意な相 関が得られなかったといえる。

\section{2. 米国超ウラン元素登録}

米国では，エネルギー省がスポンサーでハン フォード眇境健康財団に委託運営している人体登 録に関するプログラムがある。「米国超ウランお よびゥラン登録」で，PuおよびAmを主要対象と して1968年に生まれた米国超ウラン登録と，Uま でのアクチニド元素を対象として78年に生まれた 米国ウラン登録の 2 つの組織が87年に統合され， 92年にロスアラモス国立研究所等の分析支援を得 ながら，上記の名称のプログラムになっている。
実際の人体例での観察を通してそれ „んの放射性 物質の安全基準, 特に内部被曝にかかわる基準の 正当性を確加にすることを目的としている。

1991年 6 月に刊行されたハンフォード環境健康 財団の年報 ${ }^{(8)}$ によれば, 現在生存している登録者 の数は517名で, そのうち27名が全身献体者であ る。これまでに実施した解剖数は261体であるが， すべてが全身解剖ということではなく，手術前に 採取した試料も含んだ数である。なお，公開され ている文献は個人を標識番号でのみ特定し，氏名 等は明らかにしていないが, データから見て, 上 記マンハッタン計画従事者として追跡されている 者の一部あ含まれているょうである。

これまでに 5 体の全身献体からの組織中 Puの 放射化学分析が終了しており，それらから Puの 体内挙動に関し貴重な知見を得ている(9)。すなわ ち, 肝臓と骨格へのPuへの分布割合はほぼ等し いあのであり, ICRP Publ. 30(10) での記述之合っ ている。骨格筋に無視できない量のPuが沈着し, 詳細は省略するが, 結果的に全身でのPuは骨格, 肝臓,筋肉(あるいは骨格、肝脿および残りの臓器)の 3 コンパートメントの指数関数モデルで記述でき, 通過コンパートメントからそれぞれへの移行割合 は骨格 0.4 , 肝臟 0.4 , 筋肉 0.2 であり, それぞれ の生物学的半減期は骨格50年, 肝臓20年, 筋肉 10 年であるとしている。これら知見の一部はすでに ICRP Publ. 48 ${ }^{(11)}$ に生かされていて, 現在準備中 の ICRP Publ. 67(12) では, 詳細な Pu 代謝モデル が提示されることになっていて，そこにはこれら の知見がそのままの形ではないが反映される。 


\section{一参考文献一}

（1）松岡 理：“プルトニウムの安全性評価”，(1993), 日刊工業新聞.

(2) 淵上辰雄：放射線科学, 35〔2]; [7], (1992).

(3) TIEJEN, G. L. : Health Phys., 52, 625 628 (1987).

(4) Lushbaugh, C. C., et al. : Arch. Dermatol. Res., 86, 461 464 (1962).

（5）中国核工業部：“内污染の医学的処置”，(1989), 原子能出版社.
(6) Voeltz, G. L., Lawrence, J. N. P. : Health Phys., 61, 181 190 (1991).

(7) VoELTZ, G. L., et al. : CONF-830101, (1983).

(8) KATHREN, R. L., et al. : HEHF-54-90, (1991).

(9) Kathren, R. L., et al. : Health Phys., 60, 481 488 (1991).

(10) ICRP Publ. 30, (1978).

(11) ICRP Publ. 48, (1986).

(12) ICRP Publ. 67, (1994).

\section{VII. プルトニウムの安全管理 作業環境の放射線管理と 個人モニタリング}

動力炉・核燃料開発事業団 二之宮 和重

1.はじめに

動燃事業団では，1966年にPuの使用を開始し てから，ますなく30年を迎えようとしている。こ の間, 施設の安全設計や $\mathrm{Pu}$ 取扱い技術の確立之 相まって，作業場の放射線管理技術や作業者の放 射線被曝管理技術す確立され, その後着実に進展 してきている。このようにPuについては, 再処理 施設や Pu 燃料施設の操業に伴って長い経験と技 術の蓄積があるが, 本章ではこれまでのPuの安全 管理の経験として, 作業環境の放射線管理と作業 者の個人モニタリングの概要について紹介する。

\section{2. 作業環境の放射線管理}

$\mathrm{Pu}$ はグローブボックス等の密閉筞囲気の中で 取り扱われ，基本的には，作業環境においては Puの污染がないように管理されている。した がって定常的な放射線管理は, 作業環境に污染が ないことの確認が主であり，そのための表面污染 の測定と空気中放射性物質濃度の監視・測定を行 なっている。また，Pu等から放出される $\gamma$ 線や 中性子線に対しても注意が必要であり, 作業環境 に抢けるそれらの線量当量率の測定・監視も行 なっている(1)(2)。

\section{（1） 線量当量率の測定}

$\mathrm{Pu}$ 取扱い施設で取り扱われる $\mathrm{Pu}$ は数種類の $\mathrm{Pu}$ 同位体の混合物であり，また ${ }^{241} \mathrm{Pu}$ の娘核種之
して生成する ${ }^{241} \mathrm{Am}$ が混在しているため，作業環 境における $\gamma$ 線之中性子線の線量当量率の測定む 重要で, 定置式のエリアモニタによる連続測定・ 監視またはサーベイメー夕による定期的な測定を 行なっている。

$\mathrm{Pu}$ から放出されるX線と $\gamma$ 線は, その放出率, エネルギーとも極めて小さく，外部被曝管理上問 題となる放射線は ${ }^{241} \mathrm{Am}$ からの $\gamma$ 線 $(59.5 \mathrm{keV})$ で あるが, 現在の測定器はこの程度の低エネルギー 光子に対しては良好なエネルギー特性を有してお り，測定に伴う技術的課題はない。

中性子線は，主に ${ }^{238} \mathrm{Pu},{ }^{240} \mathrm{Pu}$ と ${ }^{242} \mathrm{Pu}$ の自発核 分裂によるあのと, ${ }^{18} \mathrm{O}(\alpha, n)$ 反応によるものがほ とんどで，作業場の中性子ェネルギースペクトル の測定では，第 VII-1 図に示すょうに，数 100 $\mathrm{keV}$ と $2 \sim 3 \mathrm{MeV}$ のピークと，散乱による $1 / E$ 型のエネルギースペクトルが観测されてい $\Xi^{(3)(4)}$ 。中性子線の線量当量率の測定には通常,

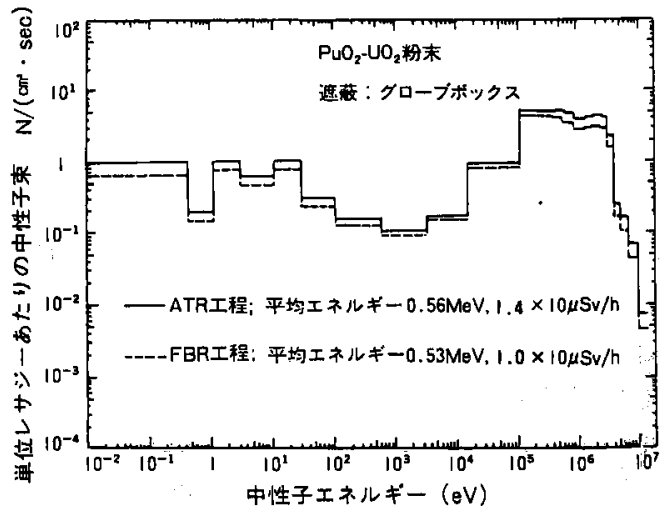

第 VII-1 図 Pu取扱い施設における代表的な中性子 エネルギースペクトル測定結果 
レムカゥンタを用いている。レムカウンタは通常 のサーベイメータと比較すると高価で重いという 欠点はあるが，中性子のエネルギーにあまり依存 せずに，放射線防護上はほぼ妥当な精度で中性子 線の線量当量率を直接測定することが可能であ り，有効である。

\section{（2）表面污染の測定}

表面污染の测定は，スミア法またはサーベイ メータによる直接測定法により行なっている。

スミア法とは，専用の沪紙で床面等測定対象の 表面を拭き取り，汇紙上の放射性物質を測定する 方法で, 通常, 拭き取り面積は $100 \mathrm{~cm}^{2}$ である。

直接測定法は，サーベイメータにより対象物表 面の污染を直接測定する方法であり，遊離性の污 染と固着性の污染の両方を测定することになる。 サーベイメータとしては, ガスフロー比例計数管 型検出器または $\mathrm{ZnS}(\mathrm{Ag})$ シンチレーション検出 器を利用したものを主に用いてきたが, 最近は, 測定器が小型軽量であることと計数ガス交换が不 要との理由で, $\mathrm{ZnS}(\mathrm{Ag})$ シンチレーション検出 器を用いたものにほぼ一本化している。

検出限界は, スミア法で $4 \times 10^{-3} \mathrm{~Bq} / \mathrm{cm}^{2}$ 程度, 直接湘定法で $2 \times 10^{-2} \mathrm{~Bq} / \mathrm{cm}^{2}$ 程度であり, 法令 に定める表面密度の限度である $4 \mathrm{~Bq} / \mathrm{cm}^{2}(\alpha$ 線) と 比較して実用上十分な感度が得られている。

\section{（3）空気中放射性物質湿度の測定}

$\mathrm{Pu}$ 取り扱う作業室の空気は，Puダストモニ タと呼ばれる連続モニタで常時, 测定・監視する か, またはエアスニッファと呼ばれる空気中ダス トの連続捕集装置でサンプリングを行なってい る。

空気中の $\mathrm{Pu}$ ダストの測定で最もやっかいな問 題が, 自然界に存在するラドン(Rn), トロン(Tn) の娘核種の存在であり,これらの核種の中には半 減期は短いが $\alpha$ 線を放出する核種が数多く存在 し，Puからの $\alpha$ 線との識別を困難にしている。 このため $\mathrm{Pu}$ ダストモニタには表面障壁型の $\mathrm{Si}$ 半 導体検出器を使用し，Puの $\alpha$ 線エネルギー領域 に着目して計数する方法により，Rn, Tn 娘核種 の影響をなるへくく受けないように工夫している。

Puダストモニタ,エアスニッファとす，集塺用 沪紙を回収し， Rn, Tn 娘核種の放射能が減衰後
(集曆後 3 日間以上経過後)，沪紙上に付着した放射 性物質を低バックグラウンドタイプの放射線検出 器で湘定し, 集塺期間中(通常 1 週間平均)の $\mathrm{Pu} の$ 空気中濃度を最終的に確定している。この場合の 検出限界は, 1 週間の平均濃度て $4 \times 10^{-10} \mathrm{~Bq}$ / $\mathrm{cm}^{3}$ 程度であり, 法令に定める $\mathrm{Pu}$ の濃度限度に 対して十分低い值の確認が可能である。

なお，集歴直後において Rn, Tn娘核種の影響 を除いてPu の空気中濃度を迅速に求めること, $\mathrm{Pu}$ の粒子径を測定すること等を目的として， $\mathrm{ZnS}(\mathrm{Ag})$ シンチレータと MCP (Microchannel plate)イメージインテンシファイアおよび画像解 析技術を応用した, Pu と Rn, Tn 娘核種による $a$ 線の弁別測定技術等の開発を進めている（写真 VII$1)^{(5)}$ 。

\section{3. 外部被曝モニタリング}

$\mathrm{Pu}$ 取扱い施設の作業者の外部被曝モニタリン グについては, 基本的に原子力発電所や RI 取扱 い事業所の場合等之大きな違いはないが， ${ }^{241} \mathrm{Am}$ からの $r$ 線，Pu同位体からの中性子線を対象之

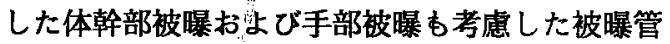
理を行なっている(6)。

\section{（1）体幹部被曝の測定}

$\mathrm{Pu}$ 取扱い施設においては，前述した通り， ${ }^{241} \mathrm{Am}$ 加らの $\gamma$ 線と, $\mathrm{Pu}$ 同位体加らの中性子線に よる被曝管理が重要である。動燃では，このよう な放射線作業場において有効で，かつ多量の作業 者のモニタリングに適した全自動読取り型の TLDバッジを開発·実用化し，1982年から公式の 線量計として使用している(写真 VII-2) ${ }^{(7)(8)}$ 。

本TLDバッジにより $\gamma$ 線, 中性子線および $\beta$ 線 の測定が可能であり, 特に, TLD素子として生 体等価の $\mathrm{Li}_{2} \mathrm{~B}_{4} \mathrm{O}_{7}(\mathrm{Cu})$ を採用していることから, $\gamma$ 線については $1 \mathrm{~cm}$ 線量当量がほぼ直接測定可能 である。また，中性子線については熱中性子とそ れ以外の中性子に分離して評価する。

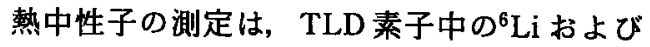
${ }^{10} \mathrm{~B}$ による $(n, \alpha)$ 反応を利用して直接行う。一方, 熱中性子以外の中性子の測定は，人体中で散乱さ れて熱中性子化し，体外に反射されて出てくる中 性子を計測する「アルべド法」を採用しており，こ 


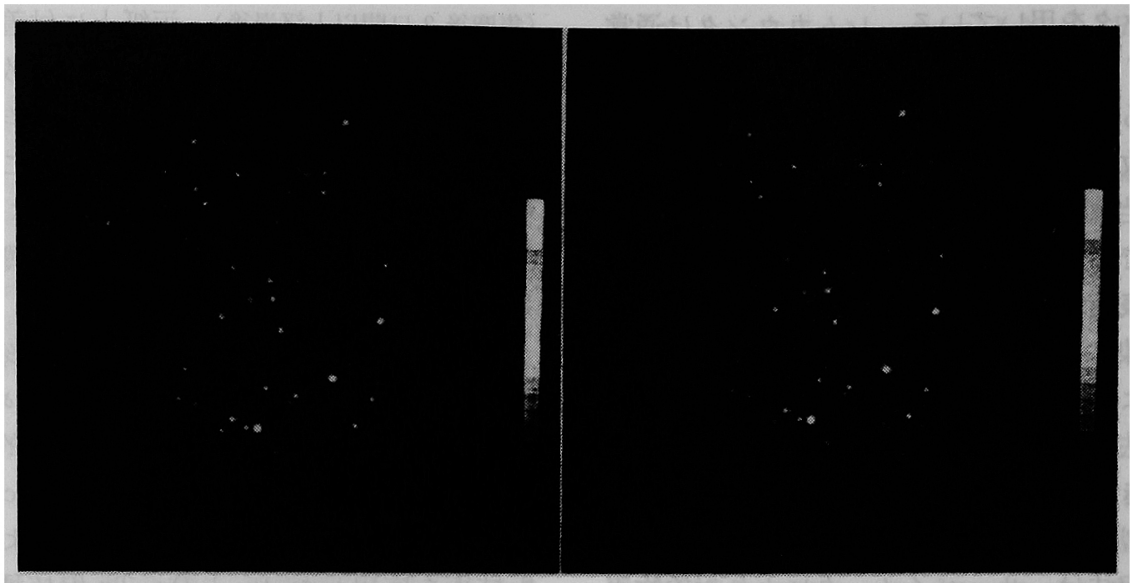

(a)

(b)

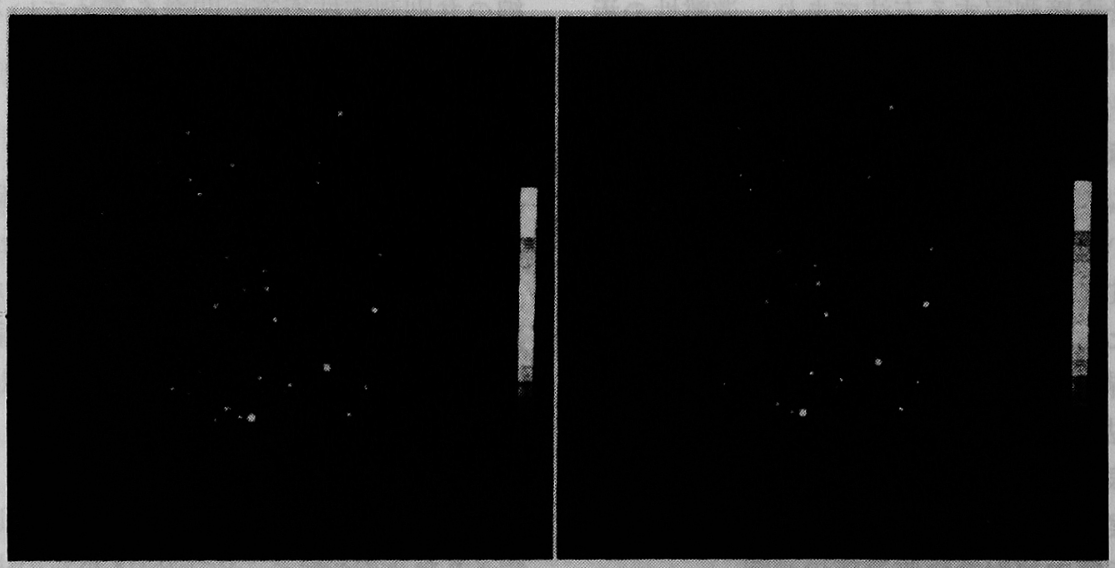

(c)

(d)

(Pu : 180dpm, Rn娘核種 : (a) 0 カウント，(b) 1,771カウント, (c) 5,475カウント，(d) 10,857カゥント) 写 衰 VII-1 $\mathrm{PuO}_{2}$ 粒子と $\mathrm{Rn}$ 娘核種による $\alpha$ 線計数の画像解析結果

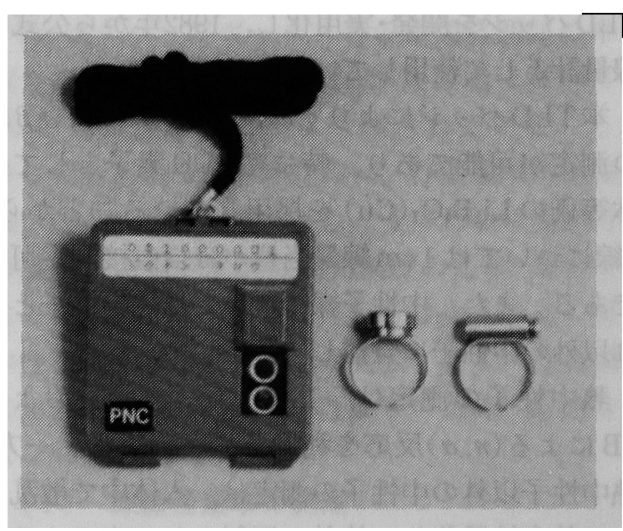

写真 VII-2 TLDバッジ(左)およびTLD 指リング線量計(右)
れにより，熱中性子から,他の測定器では湘定が困 難な中速領域の中性子を含め, 数 $\mathrm{MeV}$ までの幅広 いェネルギー範囲の中性子の測定が可能である。

アルベド法については，(1)感度のエネルギー依 存性が大きく，特に高エネルギー側で感度が大き く低下する, (2) r 線の影望を受ける, 等の問題点が あることが墏案とされていたが，Pu取扱い場に 応じた線量評価パラメータを使用することで適切 な評価が行えること (9)，およびPu取扱い施設の 作業場票囲気では $\gamma$ 線と中性子線との線量当量率 は同程度であり，このレベルでは $r$ 線と中性子線 の分離評価は実用上充分可能であること(10)を確 認している。 
作業者の被曝管理結果については，作業環境の 管理および $\gamma$ 線線量当量を指標として毎日のきめ 細かな管理を行うことにより, 中性子線も含め, 3 カ月ごとあるいは年間の線量当量の管理レベル 以内に良好に管理されている。なお最近，中性子 についてすリアルタイムで線量当量の測定が可能 な半導体式の個人線量計が開発され(11), 今後, $\mathrm{Pu}$ 取扱い施設での被曝管理用機器としての利用 が期待される。

\section{（2）末端部(手部)被莫の泪定}

$\mathrm{Pu}$ 取扱い施設では，グローブボックス越しに 手で Puを取り扱うことも多く，手部の被曝管理 す重要である。

手部の被嚗線量を测定する測定器としては, TLDを使用した小型の指りング線量計の長年の 使用実績があるが, 従来の線量計は手で一つ一つ 素子を取り出して湘定しなければならなかったた め, 湘定に大きな労力を必要としていた。そこ で, 自動読取りが可能で, かつ $70 \mu \mathrm{m}$ 線量当量が 直接測定可能な指りング線量計を開発し，個人モ ニタリングに適用を開始している(12)。

\section{4. 内部被㙋モニタリング}

$\mathrm{Pu}$ を取り扱う場合に放射線安全管理上最も配 慮しなければならないのが, 内部被曝の防止であ る。Pu取扱い施設においては，通常の状況では 作業者が Puを摄取することはない。しかし，グ ローブボックスのグローブのピンホールや配管か らの予期せぬPuの漏洩等により，作業者が Puを 摄取することがあった。このような場合には，な るべく用速かつ正確にPuの摄取量を評価するこ とが必要であり，そのために体外計測による測定 やバイオアッセイ等を実施する。

$\mathrm{Pu}$ を摄取した場合の内部被曝線量評価手順の 概略を第 VII-2 図に示す。なお, 図に示す個人モ二 タリングに先立って，Puの昅入摄取の有無を判 断する目的で,「鼻スミヤ」を実施することが多い。 これは, 沪紙付きの綿棒で作業者の睤腔内を拭き 取り，沪紙上に付着した放射能を測定する方法で あるが，Puを吸入摄取した場合には，比較的大き な粒径のPuが鼻腔内に付着していることが多く， 吸入㠌取の簡便な確認方法として有効である。

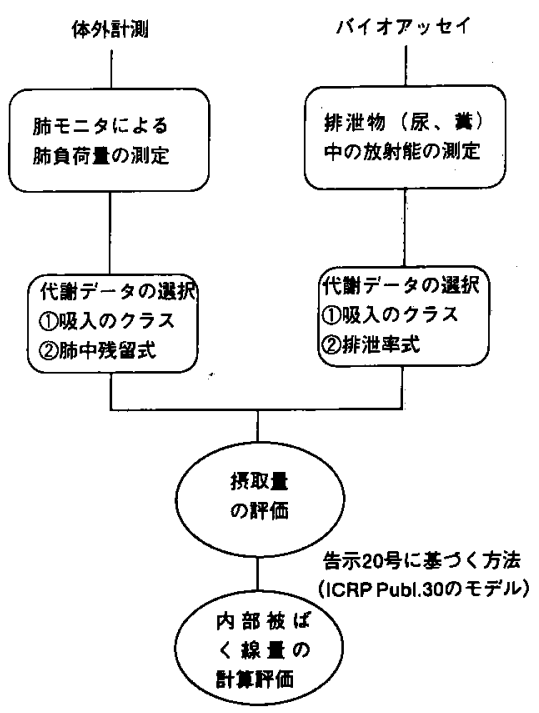

第 VII-2 図 Puを摄取した場合の内部 被曝線量評価手順

\section{（1）体外計测による珝定}

$\mathrm{Pu}$ の摄取形態としては, 経口攝取, 吸入㩒取, 傷口浸入などが考えられるが，年摄取限度(ALI) の数値からあ理解できるように，核燃料施設にお いて被曝評価上重要なものは，吸入による摄取で ある。Puを吸入した場合は当初，比較的長く肺 にとどまるため, 肺中の Puを測定・評価すること が最む効果的であり，このために用いられる測定 器は肺モニタと呼ばれる。

肺モニタはPuから放出される弱いLX線等(I ネルギー: 11.5〜23keV，放出率：4.6〜11.4\%)を体 外から測定する装置で, 低エネルギーの X 線等 をできるだけ効率よく湘定するために，NaI(T1) と CsI(T1)を組み合わせたホスゥィッチ検出器と 呼ばれる特殊な検出器を鉄室の中に備え付けたす のを用いている。しかし，放出率の小さい低エネ ルギーのX線を体の外から湘定するという测定 原理のため，低いレべルの肺中 $\mathrm{Pu}$ の検出は不可 能で, 通常, PuのALIに相当する肺負荷量の測 定は困難である。しかしこの場合も，緊急の医療 措置が必要がうかの判断等には有効である。な お, 最近諸外国において, 複数の低エネルギー用 $\mathrm{Ge}$ 検出器を組み合わせて肺モニタとして使用し ている例があり，動燃においても，肺中の $\mathrm{Pu}$ 
よび241 Am の検出性能の向上に有効かどうかの検 討を進めている(14)。

\section{（2）パイオアッセイによる評価}

上述したように，肺モニタによる測定結果は医 療措置の検討等には有効であるが, 低いレベルの $\mathrm{Pu}$ の摄取量の評価を行う場合は，バイオアッセ イ(生体試料分析)を用いる。

バイオアッセイ試料としては䔬および尿がある が，第 VI-3 図 ${ }^{(13)}$ に示す通り，Puの吸入直後に は翼に多く排泄され，現行のICRPのモデルによ れば吸入後初期 ( 5 日間程度)の翼中に, 摄取した $\mathrm{Pu}$ のうちの約半分が排泄される。したがって初 期粪中の Pu量を测定すれば, 摄取量が計算され, それにより内部被曝線量の評価が可能である。な お, バイオアッセイには, 試料の前処理(乾燥, 灰 化), $\mathrm{Pu}$ 等の分離·抽出, 湘定等, 多くの時間を要す るため, 5 日間の排泄物試料の測定には通常, 2 週 間程度必要である。

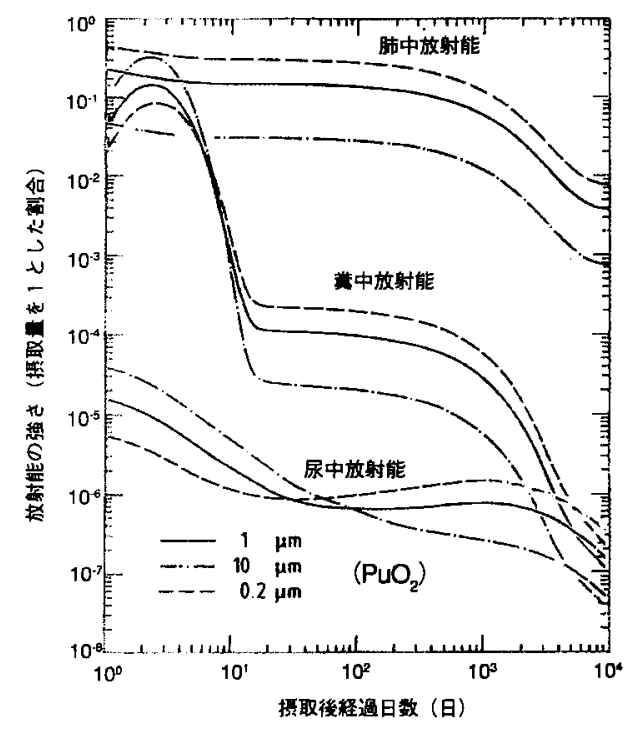

第 VII-3 図 ${ }^{239} \mathrm{Pu}$ 吸入後の肺中沈着量および排泄 放射能の変化 $\left(\mathrm{PuO}_{2}\right.$ の場合) ${ }^{(13)}$
最後に，動燃では1993年12月に法令の限度を超 える内部被曝事故が発生した。しかしこの場合の 被曝線量は,「今後50年間に受ける内部被曝線量 の合計値(預託線量当量)」が法令で定めた「年間の 線量当量の限度(実効線量当量: $50 \mathrm{mSv}$, 組織線量当 量：500 mSv)」を越えたというあのであり，法令 值を越えたことの管理上の責任は免れられない が, 被曝の程度は健康に重大な影響を及济すよう なレベルではなかった。

\section{5. まとめ}

Pu取扱い施設における作業環境の放射線管理 之作業者の個人モニタリングについて，動燃にお ける管理経験を基に記載した。Puの放射線安全 管理は,ここに記載した内容以外にあ，放射線測 定器の保守・校正, 施設からの放出モニタリング, 環境モニタリング等, 多くの項目が組み合わされ て成り立っている。今回は誌面の関係ですべての 項目を記載することはできなかったが，これらの 経験と技術は確実に蓄えられており，Pu利用に 伴う安全管理については，その確固たる基盤はす でに形成されている。

\section{一参考文献一}

（1）石黒秀治, 田子 格：原子力誌，29[8]，681 (1987).

（2）小林博英，他：動燃技報，No. 81， p.15 (1992).

(3) 中尾徳晶, 他：原子力誌，35[12]，1103 (1994).

（4）百瀬㻟磨，他：動燃技報，No. 65-11，(1988）.

（5）高崎浩司，他：動燃技報，No. 81， p.63 (1992).

(6) 二之宮和重, 桜井直行：同 上, p. 8.

（7）石黒秀治, 武田伸荘：保健物理, No. 16，305 (1981).

（8）石黒秀治, 武田伸荘：同 上, No.17, 27 (1981).

（9）百瀨琭穈，他 : PNC TN 8410 89-050, p.7 (1989).

（10）姝山寿子, 他：保健物理学会第28回研究発表会要旨 集, B-33, (1993).

(11) 中村尚司, 他 : 原子力誌, 36 [4], 337 (1994).

(12) 辻村憲雄, 他：原子力学会「1994春の年会」要旨集, M6.

(13) ICRP Publ. 54, (1987).

(14) 大塚隆宏, 他：保健物理学会第29回研究発表会要旨 集, B-39, (1994). 


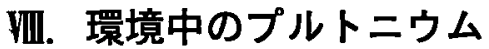

\section{秋田大学医学部 久 松 俊 -}

\section{1.はじめに}

現在, 世界の環境中に存在する $\mathrm{Pu}$ の起源は, 核実験, 核兵器製造用Pu取扱い施設および発電用 核燃料再処理工場からの流出, 核事故である。核 事故には核爆弾を搭載した航空機の墜落, 核爆弾

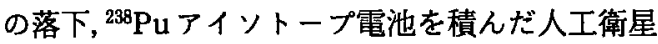
の軌道投入の失敗, 核施設内の事故,近年のチェル ノブイリ原子炉事故などが含まれる。これらに関 する全般的な記述は，国連科学委員会報告書 (UNSCEAR 報告)が参考之なる ${ }^{(1)(2)}$ 。また Pu同位 体のうち, ${ }^{239} \mathrm{Pu}$ と ${ }^{240} \mathrm{Pu}$ は放出する $\alpha$ 線のエネル ギーが近接しており，環境研究で一般的に用いら れる $\mathrm{Si}$ 半導体検出器では区別できないため, 239,240 $\mathrm{Pu}$ などと標記される。

日本の環境中に存在する ${ }^{239,240} \mathrm{Pu}$ はほとんど大 部分が核実験起源のものである。Katuragiによ れば，1980年までの東京における積算降下量は約 $44 \mathrm{~Bq} \cdot \mathrm{m}^{-2}$ であり ${ }^{(3)}$ ，これに日本全体を代表させ ると, 約 $16 \mathrm{TBq}$ (後述の ${ }^{240} \mathrm{Pu} /{ }^{239} \mathrm{Pu}$ 比を考虑して約 5 $\mathrm{kg}$ )之なる。一方，東海村の核燃料再処理施設の 運転に伴い，液体廃棄物として放出されている分 ああるが，これは総計でも核実験起源の $10^{-5}$ 程 度である。日本全体に広く薄くばらまかれる核実 験起源 $\mathrm{Pu}$ と局地的な放出である再処理工場の場 合を直接比較はできないが，周辺の海域の海水や 海産物のPu測定結果に明らかな影響は諗められ ない(4)。

\section{2. $\mathrm{Pu}$ 摄取量}

核実験起源 ${ }^{239,240} \mathrm{Pu}$ 摄取量を求めるためのパラ メー夕はBennettによって見積もられ(5), UNSCEAR 報告にも使われている。UNSCEARによ ると，実効線量預託で ${ }^{137} \mathrm{Cs}$ の $4.3 \%$ あり, ${ }^{238} \mathrm{Pu}$, ${ }^{241} \mathrm{Pu}$ を加えて 5.6\% と大きな寄与ではない(2)。 ${ }^{239} \cdot{ }^{240} \mathrm{Pu}$ の人体への経路として，吸入摄取と経口 摄取がある。Bennettによれば，北半球中緯度地 帯の吸入摄取量は1980年までで $1.2 \mathrm{~Bq}$ であり, 同時期の経口掑取量は $3.3 \mathrm{~Bq}$ と試算している。
ただ，経口摄取量については十分なデータの裹付 けがあるわけではなく，1963，64，72，74年の ニューヨークの食品中 Pu濃度を基にしているだ けである。Pu の経口摄取量のデータはそしく， このほかにイタリア ${ }^{(6)}$ と日本のデータ ${ }^{(7)(8)}$ がある のみであるが, イ夕リアの值はニューヨークと同 様である。しかし，日本の Pu摄取量は二ュー ヨークよりはるかに高い。単位降下量当たりで比 較すると1960年代では約 4 倍となる。

東京の摄取量を推定してみると，1980年までで $22 \mathrm{~Bq}$ となるが，東京の降下量はニューヨークの 約 $1 / 2$ でしかないので, 降下量当たりでは約 13 倍 となる。この原因は，海産物の摂取にあること が，食品群別にPuを分析した結果から明らかと なった。特に，海藻の寄与が高く，全体の60〜 70\%が海藻を通しての摂取である。これは，日本 人が海藻を多食するためであり，また海藻は $\mathrm{Pu}$ を濃縮することはよく知られ，モニタリングの指 標生物としてあ使われる(9)

日本の浅海では，Puの大部分は堆積物中に見 られる ${ }^{(10)}$ 。大洋の海水中Puの深度分布が測定さ れているが，近年の最大濃度は水深 $600 \mathrm{~m}$ 前後に 見られ，それ以下では急減する。ただ，海底では また上昇し，これは粒子に吸着して沈降した $\mathrm{Pu}$ が溶け出していると見られる ${ }^{(11)}$ 。再処理工場起 源の $\mathrm{Pu}$ の場合，溶存 $\mathrm{Pu}$ では $\mathrm{Pu}(\mathrm{VI})$ が，粒子状 $\mathrm{Pu}$ では Pu(IV) が支配的 ${ }^{(12)}$ と見られるが，海藻 に取り込まれた際の化学形は不明であり，表面吸 着む考えられる。

海藻に限らず，核実験起源 $\mathrm{Pu}$ の経口接種の場 合，腸管吸収率をどう取るかが問題となる。 ICRP は酸化物のような難溶性のPu化合物の腸 管吸収率は $10^{-5}$, 可溶性 Puについては $10^{-4}$ とし ていたが(13)，最近では，公策の被曝について計 算する場合，化学形不明の Puに関しては $10^{-3}$ を 取るようにした ${ }^{(14)}$ 。一方，UNSCEAR 1982年報 告では $10^{-3}$ で計算していたが，最新の報告では $10^{-5}$ としている。

\section{3. $\mathrm{Pu}$ 同位体比}

$\mathrm{Pu}$ の同位体比は環境中の Pu の起源を探る上て 重要である。核実験起源の Puの場合，核爆弾そ 
のあのに用いられる兵器級 $\mathrm{Pu}$ は, ほとんどが ${ }^{239} \mathrm{Pu} ゙$ あるが，核爆発時の中性子により高い質 量数を持つPuが生成する。核実験起源 $\mathrm{Pu}$ 全体の ${ }^{240} \mathrm{Pu} /{ }^{229} \mathrm{Pu}$ 原子数比 $\left(240 / 239\right.$ 比)は $0.18^{(15)}$ である。 この比の差を用いて兵器級 $\mathrm{Pu}$ と核実験起源 $\mathrm{Pu}$ と の分別が可能となる。これまでロッキーフラット 工場よりの $\mathrm{Pu}$ の分別 ${ }^{(16)}$ ，ネバタ核実験場よりの Puの寄与の見積り(17)などに用いられている。こ のうちネバダ実験場については外部被曝線量の見 積りにも使われ，興味深いので以下に紹介する。

ネバタ実験場の風下に当たるュタ州での小児白 血病死亡率が実験場に近い南㑡で有意に高いと 1979年に報告された ${ }^{(18)}$ 。このため，当時の被曝 線量を推定する作業の一つとしてPuを用いた研 究が行われた ${ }^{(17)}$ 。この研究では，土埕の ${ }^{137} \mathrm{Cs}, \mathrm{Pu}$ を定量し，240/239比から実験場起源のPu沈着量 を求め,これから実験場起源の ${ }^{137} \mathrm{Cs}$ 量を推定し ている。さらに, ${ }^{137} \mathrm{Cs}$ 沈着量加ら当時の外部線 量, 骨の吸収線量を計算した。その結果, 白血病 死亡率が高いとされた南部の集積線量はむしろ北 部よりも低く，また，その線量も白血病死亡率の 増加をすたらすには低すぎる值であった。土㙲中 のPuは，実験場から運ばれたものと，大規模核 爆発による世界的なPu降下によるあのが混在す る。しかし、ネバダでの実験は，爆発の収率が高 くないため，降下物中の $240 / 239$ 比が低くなり(平 均で0.032)，高収率爆発の多い，世界的なPu降下 の比(0.18) とは異なる。これを利用して実験場か らの寄与の見積りが行われた。

さらに, ユタ州の 2 つの眝水池の堆積物を用い て,ネバタ実験場からのCsとPuの降下率を推定 した ${ }^{(19)}$ 。ソルトレイク市近くのDeer Creek眝水 池の堆積物は，第 V-1 図に見られるような非常 にきれいな樑度分布が見られた。図の横軸は，原 点を最も深度の大きい点に取り, 深度 0 を右側に 取ってある。試料の採取年は1982年である。

実験場からの降下物は1953，55，57年に多かっ たが，世界的な降下のピークは1963年に見られ た。第 Vil-2 図に，東京における Pu降下量(20)(21) をプロットしたが，60年以前のパターンが第 VII1 図とは大きく異なっている。第 VIII-1 図で，Pu 嶩度の 2 番目のピークが世界的な降下のピークに

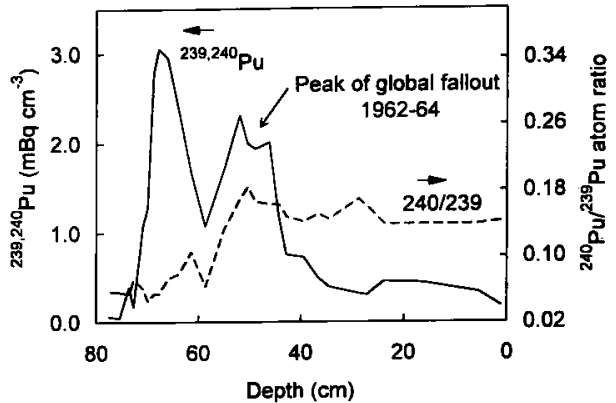

第 V-1 図 ネバダ核実験場からの降下物を受けた Deer Creek 貯水池堆積物中の Pu 濃度 および ${ }^{240} \mathrm{Pu} /{ }^{239} \mathrm{Pu}$ 原子比 ${ }^{(19)}$

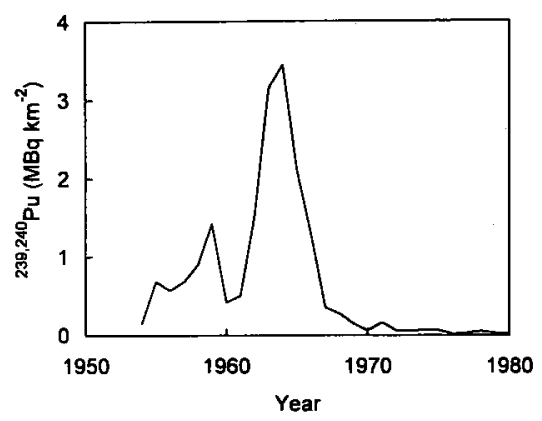

第 V-2 図 東京における Pu降下量(20)(21)

相当することが240/239比より読み取れ，最初の大 きなピークはその240/239比が低いことから，実 験場の寄与が大きいことがわかる。実験場からの $\mathrm{Pu}$ の240/239比は実験ごとに大きく変化するとは いえ，世界的な Pu降下に比較すると低いことは 確かである。実験場の比をゼ口と仮定する，ある いは1951 57年の Puがすべてネバダ起源である と仮定する、またはネバダからの240/239比の平均 值を使うなどとしてネバダからの寄与を求めてお り，土壤からの結果と比較的よく一致しだ。

環境試料中の $240 / 239$ 比を求めるにはマススペ クトロメトリーが有効であり，先にあげた研究で もこれが使われている。しかし，環境試料中の微 量の Pu の240/239比を正確に求めるには，ほとん ど専用とした機器を常備する必要があり，困難が

*ネバタ,ュタ、アリソナ州の当時の小児について，そ の後の甲状腺腫鹐の研究が最近発表されており，実 臨場からの ${ }^{131}$ Iによる推定甲状腺被嚗量と良性, 悪性 を含む腫瘍の発生率が統計学的に有意な相関を示し ている(22)。腫㾺の約半分は悪性であったが，悪性腫 誼についての線量との相関は，傾向があるものの例 数が少ないこともおり，有意ではなかった。 
多い。このため, 低エネルギー光子検出器と $\alpha$ 線 検出器を組み合わせた方法 ${ }^{(23)}$ などが考案されて いる。発電用原子炬燃料再処理に伴うPuには， $\alpha$ 線スペクトル上で容易に分別可能な ${ }^{238} \mathrm{Pu}$ が含ま れるため，これを用いて再処理からのPu 之核実 験起源のPuの分別が可能となる。チェルノブイ リ事故の際に，日本でも空気中 Pu濃度の僅かな 増加が認められたが, ${ }^{238} \mathrm{Pu} /{ }^{239,240} \mathrm{Pu}$ 比より，こ れが事故起源の $\mathrm{Pu}$ であることが確かめられ $た^{(24)}$ 。このほか， $\beta$ 放射体の ${ }^{241} \mathrm{Pu}$ も利用可能と 思われる(25)。

\section{4. 土堷中 Puの化学形}

最後に, 土壌中での Puの化学形に関する最近 の研究に触れておきたい。土壤中での $\mathrm{Pu}$ に限ら ず, 環境中での Puの化学形はほとんど不明であ る。僅かに，先に述べた水圈環境でのPuの価数 が見るべき成果といえる程度である。この問題が 重要なのは，生物の吸収率がキレート刘などに よって大きく影㫼されることが，広く認められて いるためである。環境中で吸収率に影響を与える ような何らかの天然のキレート剤が存在するとし たら，その本体を明らかにしなければならない。 また，そのようなキレート剤の作用以外にも， $\mathrm{Pu}$ の化学形が変化すれば, 大なり小なり生物の 吸収率が変わる。例えば，それは土㙵中 $\mathrm{Pu}$ の植 物吸収率経年変化のような形で現れることも考え られる。植物吸収率の変化を検討する実験はいる いろと行われているが，増加する場合や反対に減 少する場合が見られ，はっきりとした結論は出て いない(26) (28)。

さて，土壤中での化学形を探る試みとして，ト リメチルクロロシランによってフミン酸をジメチ ルフォルムアルデヒドに溶かし出すことが行われ た ${ }^{(29)}$ 。これは比較的穞やかな抽出法であり，フ ミン酸は Puや鉄を抱えたまま溶出する。溶出液 を非水溶媒系のゲル沪過カラムに掛けると，七ラ フィールド核燃料再処理工場よりのPuを含む塩 性沼沢地の土壤の場合, $\mathrm{Pu}$ は行子量 $1 \sim 2.5 \mathrm{kDa}$ と約 $50 \mathrm{kDa}$ のつのピークに伃離できた。この 方法のPu抽出率が70\%と高いことも特徽であろ う。まだ,この結果から化学形に関する情報は直
接出て来ないが，有望な手法と考えられる。

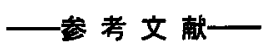

(1) UNSCEAR 1982 Rep., (1982), United Nations.

(2) UNSCEAR 1993 Rep., (1993), United Nations.

(3) Katuragi, Y., et al. : Pap. Meteorol. Geophys., 33, 85 (1982).

(4) Yamato, A. : J. Radioanal. Nucl. Chem. Articles, 156, 349 (1992).

(5) BENNETT, B.G. : Environmental aspect of americium, $H A S L-348$, (1978).

(6) Clemente, G. F., et al. : IAEA-SM-237/64, p. 257 (1979).

(7) Hisamatsu, S., et al. : Health Phys., 51, 479 (1986).

(8) Hisamatsu, S., et al. : ibid., 52, 193 (1987).

(9) HAYASH, N., et al. : J. Radioanal. Nucl. Chem. Articles, 138, 331 (1990).

(10) Nakamura, K., Nagaya, Y. : ibid., 138, 153 (1990).

(11) NAKANISHI, T., et al. : ibid., 138, 321 (1990).

(12) Nelson, D.M., Lovetr, M.B. : Nature, 276, 599 (1978).

(13) ICRP Publ. 30, Limits for Intakes of Radionuclides by Workers, Part 1, (1979), Pergamon Press, Oxford.

(14) ICRP Publ. 56, Age-dependent Doses to Members of the Public from Intake of Radionuclides, Part 1, (1989), Pergamon Press, Oxford.

(15) KREY, P. W., et al. : IAEA-SM-199/39, p. 671 (1976).

(16) KREY, P.W., KRAJEWSKI, B. T. : HASL-249, p.I-67 (1972).

(17) BECK, H. L., KREY, P. W. : Science, 220, 18 (1983).

(18) Lyon, J. L., et al. : Nucl. Eng. J. Med., 300, 397 (1979).

(19) KREY, P. W., et al. : Health Phys., 59, 541 (1990).

(20) MIYAKE, Y., et al.: "Radiation Research", p.940 (1979), Toppan, Tokyo.

(21) Katsuragi, Y., et al. : Pap. Meteorol. Geophys., 33, 95 (1982).

(22) KeRBer, R. A., et al. : J. Am. Med. Assoc., 270, 2076 (1993).

(23) Hisamatsu, S., Sakanoue, M. : Nucl. Instrum. Methods, 226, 1 (1984).

(24) Hirose, K., Sugimura, Y.:J. Radioanal. Nucl. Chem. Articles, 138, 127 (1990).

(25) Yамамото, A., et al. : ibid., 138, 365 (1990).

(26) Romney, E. M., et al. : Health Phys., 19, 487 (1970).

(27) Popplewell, D. S., et al. : Sci. Total Environ., 38, 173 (1984).

(28) NisbeT, A. F., Shaw, S. : J. Environ. Radioact., 23, 1 (1994).

(29) Bulman, R. A., et al. : Sci. Total Environ, 114, 215 (1992). 


\section{IX.おわりに}

松 岡 理

$\mathrm{Pu}$ の安全性を新しい角度から論じた 8つの論 文をお読みになって，今までの Puに関する知識 に少しであ新しい違った角度のあのが付け加わっ たとすれば，本「特集」を組んだ目標がかなり達成 されたといえよう。

私自身の読後感は, 我が国の現況からは，Pu 利用の現状が世界の中で突出していると非難され ることがあるが，ようやくヨーロッパの先進国に 追い付いたという感じである。

安全性の化学については，安全性を公衆に説く ための基礎的資料はまだ十分整っているとはいえ ず, 今後 Pu安全性のための実証データの採取が 期待される。

$\mathrm{Pu}$ の代謝の情報はかなりのものが得られたが， 動物のあのであり，今後人体での代謝にどれだけ 近づけるかが課題であろう。

$\mathbf{P u}$ の生物影整は人体例がない今日，また今後 あ集団的な障害発生は認められる可能性がないの で，どれだけ人類での影響を精度高く評価できる ようにするかが最大の課題であろう。

Pu の废学について過去の事例がレビューされ たが，米国の超ウラン元素被曝者登録などの地道 な努力しか将来性はないことを示している。

モニタリングでは，動燃事業団での事故の実態 からよくわかるように，わが国の Pu 取扱いは諸 外国に比べ，極めて安全性の高いレベルである が，今後の大規模の取扱いに際してもこの安全記 録が保たれることを期待したい。

環境中のPuでは，降下量に比べて異常に高い 日本人の体内量が海藻の摂取に由来するという説 は極めて興味を持たれることである。

今や原子力，ことにリサイクル路線は社会的に は激しい逆風が吹いている。特に問題なのは，原 子力に対する批判が公衆を味方につけることで目 的を達成しようとすることである。他の産業でこ のような戦略が取られた例はあまりないのであ る。
公衆に対する批判側のアプローチは 3 つの方向 がある。第 1 はPuの過大な危険性のPR，第 2 は $\mathrm{Pu}$ の核兵器転用の可能性の強調。第 3 は $\mathrm{Pu}$ 路線 が経済的に成立しないという PRである。ここで は第 1 のPuの過大な危険性の指摘についての公 临に対するPR活動のあり方について考えて見た い。

まず情報公開の問題点について考えて見る。 「あかつき丸|以来の批判側の重点は情報公開の要 求におかれ，情報の不足をよいことにしての過大 な事故想定に基づく公衆への反対宣伝がなされ た。しかし，この反対宣伝に対して我々健康影響 の専門家は公衆にその誇大さの誤りを正そうとし ても，残念ながら情報が公開されていないので, 十分な反論ができなかったのである。当局側の立 場は輸送容器はいかなる場合も破損することはな く，Puは容器の外に出ることはないとしている。 理由として, IAEA の輸送容器の安全基準を挙 げ, $9 \mathrm{~m}$ 落下試験, $800^{\circ} \mathrm{C}, 30 \mathrm{~min}$ の耐熱テスト, 水深 $15 \mathrm{~m}$ での $8 \mathrm{~h}$ 保持などを持ち出しても, 公衆 はそんなむのは信じないで，燃えたPuが一面に 広がり多くの人が被曝するとか，海に沈んで溶け たPuで海水の広範な污染が広がるという反対派 の宣伝を信じるのである。容器の安全基準が国内 外の全輸送経路，全事故で安全が保障されている ことを具体的に立証しなければ公衆は信じないの である。チェルノブイリ以来, 容器から放射性物 質が漏れる事故はあり得ないということは説得力 を全く失っているのである。

核防護の立場からの情報非公開の論理には $2 つ$ があり，1つは奪取の恐れからの情報制限であ り，あう1つは商業機密である。前者は，世界中 でまだ一度む起きたことのないテロリストによる 奪取に備えるという過剩な対策であり，後者は公 衆に容器の安全性を説明するのにはほとんど関係 のない過剩な解釈といえる。

プルサーマルの時代に備えて開かれた原子力へ の努力が今後必要である。このため，原子灯事故 対策加ら核燃料輸送事故対策へ拡大が必要であ る。それは専門家でなく，公䍃が納得するもので なければならない。 